\title{
Enterobacter: ONE BACTERIUM - MULTIPLE FUNCTIONS
}

\author{
P. M. STATHOPOULOU*, E. ASIMAKIS* AND G. TSIAMIS \\ Department of Environmental Engineering, University of Patras, 30100, Agrinio, \\ Greece; gtsiamis@upatras.gr \\ "Both authors contributed equally to this work
}

\begin{abstract}
SUMMARY
Insects represent the most successful taxon of eukaryotic life, being able to colonize almost all environments. Microbial symbiomes associated with insects, impact important physiologies, and influence nutritional and immune system status, and ultimately, fitness. A variety of bacterial phyla are commonly present in insect guts, including Gammaproteobacteria, Alphaproteobacteria, Betaproteobacteria, Bacteroidetes, Firmicutes, Clostridia, Spirochetes, Verrucomicrobia, Actinobacteria, and others. Among them, the genus Enterobacter has been recognized as a dominant inhabitant of the gut for several important insect species, indicating an essential functional role for this taxon. Here, we review the known Enterobacter functional diversity among insects with respect to insect development, host exploitation, reproduction, and interactions with other organisms, in an attempt to provide an overview of the traits that have resulted in their evolutionary success. Many strains of Enterobacter species are not simply insect commensals but confer beneficial traits to their hosts that primarily fall into two categories: provision and degradation of nutrients and protection from pathogens.
\end{abstract}

Key Words: Microbial symbiomes, endosymbiotic bacteria, bacterial functional diversity, mutualisms, commensalisms, pathogenic relationships, nutrient degradation, nutrient provision, pathogen protection

\section{INTRODUCTION}

Microorganisms are well recognized as essential members of the biosphere. Over billions of years they have evolved into every conceivable niche on the planet. Microorganisms reshaped the oceans and atmosphere and gave rise to conditions conducive to the development of multicellular organisms (Gibbons and Gilbert 2015). Microbial diversity and distribution were mostly inaccessible and underestimated before the advent of molecular fingerprinting and high-throughput sequencing technologies, which now allow us to circumvent culture-based approaches (Fierer and Lennon 2011; Whitman et al. 1998).

\section{7}

J. Hendrichs, R. Pereira and M. J. B. Vreysen (eds.), Area-Wide Integrated Pest Management: Development and Field Application, pp. 917-945. CRC Press, Boca Raton, Florida, USA.

(C) 2021 IAEA 
Bacteria and archaea estimates continue to rise within an increasing number of environments sequenced using advanced molecular techniques, with the number of existing microbial species predicted to reach millions (Brown et al. 2015; Williams et al. 2017; Zaremba-Niedzwiedzka et al. 2017).

The term symbiosis originates from the Greek word "symbioun" meaning "to live together"; it was defined by Anton de Bary in 1879 as "the living together of two dissimilar organisms, usually in intimate association, and usually to the benefit of at least one partner" (Bary 1879). Symbiotic bacteria are omnipresent in all types of ecosystems, having a significant impact on eukaryotic evolution and diversity (Martin and Schwab 2012; McFall-Ngai 2007; Ruby et al. 2004). Although considerable attention has been given to pathogenic bacteria, pathogens are a minute minority of animal symbionts.

Microbial symbioses are generally categorized as parasitism, commensalism, or mutualism, though some relationships may wander across these defined boundaries depending on evolutionary processes, changes in environmental conditions and/or health state of the host/symbionts (Webster 2014). Host development, defence, nutrient assimilation and disease, in humans and other animals, is influenced by microbial mutualisms, commensalisms and pathogenic relationships (Eren et al. 2015). The development of next-generation DNA sequencing platforms has allowed an in-depth understanding of the composition of the microbial populations inhabiting different hosts and symbiosis research has focused on associations that (i) have economic importance, (ii) have implications for human health, or (iii) offer ecologically fascinating insights (Webster 2014).

It is estimated that the majority of members of the largest class of invertebrates, i.e. Insecta, are involved in some type of symbiosis, with most of these relations being shared with bacteria. Microorganisms can colonize the insect exoskeleton, the gut and haemocoel, and are present within some insect cells. The microbiota may account for $1-10 \%$ of the insect biomass, implying that the insect, as well as any other higher organism, can be regarded as a multi-organismal entity (Douglas 2015). Bacterial symbionts are equally prevalent in mammals and insects; however, the bacterial diversity in insect digestive tracts is generally low and rarely exceeds a few tens of species (Colman et al. 2012). Several immunological, physiological and morphological hypotheses have been proposed to explain that fact (Broderick and Lemaitre 2012; Engel and Moran 2013). The lack of adaptive immune function in invertebrates might partly explain this low diversity (McFall-Ngai 2007).

\section{INSECT SYMBIONTS}

Insect-associated microorganisms cover an immense range of functions and are known to upgrade nutrient-poor diets; aid digestion of recalcitrant food components; protect from predators, parasites, and pathogens; contribute to inter- and intraspecific communication; affect efficiency of disease vectors; and govern mating and reproductive systems (Engel and Moran 2013; Gil and Latorre 2019). 


\subsection{Obligate Mutualistic Symbionts}

Insects that depend exclusively on nutritionally restricted diets such as plant sap, vertebrate blood and woody material, commonly possess obligate mutualistic symbionts that are involved in the provision of essential nutrients or the degradation of food materials (Engel and Moran 2013; Engel et al. 2016; Latorre and ManzanoMarín 2017). At least $10 \%$ of all insect species depend on obligate nutritional symbioses where bacteria are required to synthesize nutrients that are absent in the diets of their hosts (Wernegreen 2004). Aphids provide an example of such obligate endosymbiosis since all aphids harbour endosymbiotic bacteria (i.e. microorganisms that live inside host cells or tissues) of the genus Buchnera in specialized host cells called 'bacteriocytes' (Manzano-Marín et al. 2016). Other obligatory endosymbionts include Wigglesworthia in tsetse flies (Akman et al. 2002), Blochmannia in carpenter ants (Williams and Wernegreen 2010), Baumannia in sharpshooters (Wu et al. 2006), Carsonella in psyllids (Nakabachi et al. 2006) and Tremblaya in mealybugs (Szabó et al. 2017). In a broader definition in the same category, we can include Candidatus Erwinia dacicola in the olive fruit fly Bactrocera oleae (Capuzzo et al. 2005; BenYosef et al. 2014). These intracellular mutualists commonly have the following biological features: (a) they are located inside bacteriocytes, (b) are essential for fitness, (c) are transmitted maternally, and (d) display strict host-symbiont coevolutionary patterns (Bourtzis and Miller 2008).

\section{2. "Facultative" Symbiotic Bacteria}

In addition to obligate symbionts, many insects harbour "facultative" symbiotic bacteria, which are not essential for either host survival or reproduction and are typically maintained with a patchy distribution in host populations. Some facultative symbionts, like Wolbachia, Spiroplasma and Cardinium, are famous as reproductive manipulators in insects, affecting host reproduction by inducing male-killing, feminization, parthenogenesis or cytoplasmic incompatibility (Zchori-Fein and Perlman 2004; Doudoumis et al. 2013, 2017; Mateos et al. 2018). It has been speculated that these reproductive manipulators are not only harmful agents but also accelerators of host speciation due to reproductive isolation between infected and uninfected hosts. At the same time, Wolbachia has been shown, under certain conditions, to protect their hosts from insect pathogenic viruses as well as to prevent the establishment and transmission of major human pathogens like dengue and chikungunya viruses and the malaria parasite Plasmodium (Schmidt et al. 2017; Tan et al. 2017; Ant et al. 2018).

\subsection{Gut Microbiota}

Research conducted mainly in the last ten years, has resulted in tremendous progress in the field of gut microbiota and their impact on host metabolism. In general, gut microorganisms provide several nutritional functions to their hosts, and in return, hosts provide symbiotic microorganisms with a stable, protected, and nutrient-rich environment (Kohl et al. 2014). All animals assemble and maintain a diverse but host- 
specific gut microbial community. Aside from the ubiquitous gut microflora in vertebrates, numerous invertebrates harbour endosymbiotic microorganisms inside their body cavity (Feldhaar 2011). It is believed that the gut microbiota can be considered as a bacterial organ, which is integrated into the biological system of the host (Sandeva et al. 2018). Gut microorganisms are also considered endosymbionts (Moya et al. 2008), although they are localized extracellularly within the gut lumen and their persistence within the gut could range from transient visitors to permanent inhabitants (Feldhaar 2011). Gut microorganisms produce a diverse metabolite repertoire from the anaerobic fermentation of undigested dietary components that reach the colon, and from endogenous compounds that are generated by the microorganisms themselves and their hosts (Rooks and Garrett 2016). Increased availability of technologies that profile microbial communities revealed that gut microorganisms are distinct from those of other characterized habitats in the biosphere, which indicates that strong selective forces differentiated gut-dwelling bacteria regardless of their lineage (Ley et al. 2008).

The basic structure of the digestive tract is similar across insects, although they possess a diversity of modifications associated with adaptations to specialized niches and feeding habits, and many of these specializations have evolved for housing gut microorganisms in specific gut compartments (Engel and Moran 2013; Pereira and Berry 2017). A variety of bacterial phyla are commonly present in insect guts, including Gammaproteobacteria, Alphaproteobacteria, Betaproteobacteria, Bacteroidetes, Firmicutes, including Lactobacillus and Bacillus species, Clostridia, Spirochetes, Verrucomicrobia, Actinobacteria, and others (Colman et al. 2012). The contribution of microorganisms, particularly gut microorganisms, to insect function is highly relevant from several perspectives, relevant to medicine, agriculture, and ecology (Douglas 2015).

\subsection{Unveiling the Black Box of Symbiotic Associations}

Characterization, exploitation and management of the insect-microbial symbiotic associations can contribute significantly to the control of agricultural pests and disease vectors. Recent advances in "omics", such as metagenomics, metatranscriptomics, and metaproteomics, have gradually unveiled the black box of symbiotic systems. However, capturing the properties of insect microbiota has been challenging due to the high variability in composition between individuals and closely related species (Pernice et al. 2014). Several biological and ecological factors such as age, genetics and environment have been proposed to explain insect microbiota composition. However, diet is one of the main factors driving variation in the composition of the gut microbiota in vertebrates and invertebrates. In insects, host diet composition has been shown to shape the microbiota composition regardless of taxonomy and geography of the specimens (Colman et al. 2012; Chandler et al. 2011; Yun et al. 2014).

Food itself can be a vector of commensals, and different diets will provide microbial inoculates of different community compositions. Also, one major difference between the human and insect microbiota is that the majority of the insect bacteria seem to be aerobic and therefore capable of digesting food outside the insect. This 
function may contribute to explaining why host diet is such a key driver of microbiota composition and explain why bacteria commonly associated with insects are very rare in diverse mammalian species and vice versa (Chandler et al. 2011; Pernice et al. 2014). Some insect-associated microorganisms are related to microbial taxa found in other animals, e.g. Enterobacteriaceae and other Gammaproteobacteria, Firmicutes and Bacteroidetes, but others are absent from any other animal and the external environment (e.g. many protists of the class Parabasalia are found exclusively within termites (Brune and Dietrich 2015)).

\section{ENTEROBACTER A DOMINANT TAXON OF GUT MICROBIOTA WITH MULTIPLE ROLES}

Members of the Enterobacteriaceae family are facultatively anaerobic, Gram-negative rods that are catalase-positive and oxidase-negative (Brenner et al. 1984). Currently, the family comprises 51 genera (Table 1) and 238 species. The number of species displays a wide divergence with a range of 1 to 22 per genus. Twenty-two genera contain only one species, while seven genera have more than ten species (Octavia and Lan 2014).

Table 1. The genera (51) of the family Enterobacteriaceae

Arsenophonus (1991), Biostraticola (2008), Brenneria (1999), Buchnera (1991), Budvicia (1985), Buttiauxella (1982), Cedecea (1981), Citrobacter (1932), Cosenzaea (2011), Cronobacter (2008), Dickeya (2005), Edwardsiella (1965), Enterobacter (1960), Erwinia (1920), Escherichia (1919), Ewingella (1984), Gibbsiella (2011), Hafnia (1954), Klebsiella (1885), Kluyvera (1981), Leclercia (1987), Leminorella (1985), Lonsdalea (2012), Mangrovibacter (2010), Moellerella (1984), Morganella (1943), Obesumbacterium (1963), Pantoea (1989), Pectobacterium (1945), Phaseolibacter (2013), Photorhabdus (1993), Plesiomonas (1962), Pragia (1988), Proteus (1885), Providencia (1962), Rahnella (1981), Raoultella (2001), Saccharobacter (1990), Salmonella (1990), Samsonia (2001), Serratia (1823), Shigella (1919), Shimwellia (2010), Sodalis (1999), Tatumella (1982), Thorsellia (2006), Trabulsiella (1992), Wigglesworthia (1995), Xenorhabdus (1979), Yersinia (1944), and Yokenella (1985).

${ }^{*}$ The year the genus was proposed is listed in parentheses after the genus name; also, the genera of the family that have been characterized in insects are highlighted with bold text

Numerous applications use members of Enterobacteriaceae, including biocontrol in agriculture, production of recombinant proteins and non-protein products, control of infectious diseases, anticancer agents, biowaste recycling, and bioremediation (Watanabe et al. 2000; Zhu et al. 2011; Zhang et al. 2012; Zhao et al. 2012).

The family Enterobacteriaceae is ubiquitous, and many species can exist as freeliving in diverse ecological niches, both terrestrial and aquatic, and some are associated with animals, plants, or insects only (Octavia and Lan 2014). For convenience, the members are broadly categorized into three types: (1) those that can cause human infections or are primarily associated with human/animals and the environment, (2) those that are associated with plants or plant pathogens and the environment, and (3) those that are associated with insects or are endosymbionts. 
The Enterobacteriaceae (Proteobacteria) are considered as one of the most dominant bacteria families associated with insects (Drew and Lloyd 1987; Behar et al. 2005; Jurkevitch 2011; Rizzi et al. 2013; Wang et al. 2014; Cambon et al. 2018). They gave rise to a variety of symbiotic forms, from the loosely associated commensals, often designated as secondary (S) symbionts, to obligate mutualists, called primary (P) symbionts (Husník et al. 2011). Many enterobacteria are also opportunistic pathogens.

The genus Enterobacter was first described by Hormaeche and Edwards (1960) and was named for the organisms' predominant natural habitat, the intestines of animals (from Greek enteron, meaning "intestine"). Enterobacter is a genus of common Gram-negative, facultatively anaerobic, rod-shaped, non-spore-forming bacteria of the family Enterobacteriaceae. The genus is polyphyletic based on the $16 \mathrm{~S}$ rDNA sequence, with 14 lineages scattered across the 16S rDNA tree.

The taxonomy of Enterobacter has a complicated history, with several species transferred to and from this genus. The older species were assigned to the genus based on DNA-DNA hybridization values and phenotypic data; whereas the more recently described taxa rely on $16 \mathrm{~S}$ rRNA gene- and rpoB-sequencing for genus allocation. It has been previously acknowledged that Enterobacter contains species which should be transferred to other genera. The polyphyletic nature of the genus makes it difficult to assign novel species to Enterobacter unless the strains cluster with the type species (E. cloacae) of the genus (Brady et al. 2013).

Members of the Enterobacter can be found in soil, water, sewage, vegetable and fruits, plants, terrestrial and aquatic environments. They can be isolated from the intestinal tracts of humans and other animals as commensals, but they are also significant human pathogens (Hoffmann and Roggenkamp 2003; Hoffmann et al. 2005; Davin-Regli and Pagès 2015).

Interestingly, Enterobacter spp. have been recognized as inhabitants of the gut of several insect species, suggesting that this genus may play various and vital roles (Vasanthakumar et al. 2006; Geiger et al. 2009; Jiang et al. 2012; Gujjar et al. 2017). In this respect, we reviewed the known Enterobacter diversity among insects in relation to the functional role in insect development, host exploitation, reproduction, and interactions with other organisms, in order to recognise the traits that have resulted in their evolutionary success. Many Enterobacter strains are not simply insect commensals but confer beneficial traits to their hosts that primarily fall into two categories: provision/degradation of nutrients and protection from pathogens.

\subsection{Enterobacter and Nutrient Bioavailability}

Many insects derive nutritional advantage from persistent associations with microorganisms that variously synthesize essential nutrients or digest and detoxify ingested food (Douglas 2009). These persistent relationships are symbioses, and the species of the genus Enterobacter often plays a leading role (Table 2). Endosymbiotic Enterobacter species add nutritional supplements to their host diet, most of the times in cooperation with other members of the insect gut microbiota, like Klebsiella, Pectobacterium or Citrobacter. In these interactions, the primary nutrient contributor may switch between the various bacterial species of these genera. 
Table 2. Enterobacter species provide nutritional supplements to their host diet

\begin{tabular}{|c|c|c|c|c|c|}
\hline Species & $\begin{array}{c}\text { Strain } \\
\text { Accession } \\
\text { Number }\end{array}$ & \multicolumn{2}{|l|}{ Host } & Function & Reference \\
\hline $\begin{array}{l}\text { E. agglome- } \\
\text { rans }\end{array}$ & $\begin{array}{c}\text { Not } \\
\text { available }\end{array}$ & $\begin{array}{c}\text { Coptotermes } \\
\text { formosanus } \text { Shiraki }\end{array}$ & $\begin{array}{c}\text { Formosan } \\
\text { subterra- } \\
\text { nean } \\
\text { termite }\end{array}$ & Nitrogen-fixing & $\begin{array}{c}\text { Potrikus And } \\
\text { Breznak } \\
1977\end{array}$ \\
\hline E. $s p$. & $\begin{array}{c}\text { Not } \\
\text { available }\end{array}$ & $\begin{array}{c}\text { Coptotermes } \\
\text { acinaciformis } \\
\text { (Frogatt), } \\
\text { Coptotermes } \\
\text { lacteus } \\
\text { (Froggatt), } \\
\text { Cryptotennes } \\
\text { primus Hill, } \\
\text { Heterotermes } \\
\text { ferox (Froggatt), } \\
\text { Mastotennes } \\
\text { darwiniensis } \\
\text { Froggatt, } \\
\text { Nasutitermes } \\
\text { graveolus (Hill), } \\
\text { Schedorhinoter- } \\
\text { mes intermedius } \\
\text { (Brauer) }\end{array}$ & Termites & Nitrogen-fixing & $\begin{array}{c}\text { Eutick et al. } \\
1978\end{array}$ \\
\hline $\begin{array}{l}\text { E. agglome- } \\
\text { rans }\end{array}$ & \multirow{3}{*}{$\begin{array}{c}\text { Not } \\
\text { available }\end{array}$} & $\begin{array}{c}\text { Dendroctonus } \\
\text { terebrans (Olivier) }\end{array}$ & \multirow{3}{*}{ Bark beetles } & \multirow{3}{*}{ Nitrogen-fixing } & \multirow{3}{*}{$\begin{array}{c}\text { Bridges } \\
1981\end{array}$} \\
\hline E.sp. & & $\begin{array}{l}\text { D. frontalis } \\
\text { Zimmermann }\end{array}$ & & & \\
\hline $\begin{array}{c}\text { E. } \\
\text { aerogenes }\end{array}$ & & $\begin{array}{l}\text { Ips avulsus } \\
\text { (Eichhoff) }\end{array}$ & & & \\
\hline E. cloacae & $\begin{array}{c}\text { Not } \\
\text { available }\end{array}$ & $\begin{array}{l}\text { Bactrocera tryoni } \\
\text { (Froggatt) }\end{array}$ & $\begin{array}{l}\text { Queensland } \\
\text { fruit fly }\end{array}$ & Nitrogen-fixing & $\begin{array}{c}\text { Drew and } \\
\text { Lloyd 1987; } \\
\text { Murphy et } \\
\text { al. } 1994\end{array}$ \\
\hline E. sp. & $\begin{array}{c}\text { Not } \\
\text { available }\end{array}$ & $\begin{array}{c}\text { Anoplophora } \\
\text { chinensis } \\
\text { (Forster) }\end{array}$ & $\begin{array}{l}\text { Wood- } \\
\text { boring } \\
\text { beetle }\end{array}$ & Nitrogen-fixing & $\begin{array}{l}\text { Rizzi et al. } \\
\quad 2013\end{array}$ \\
\hline \multirow[b]{2}{*}{ E. sp. } & $\begin{array}{l}\text { AB673459 } \\
\text { AB673457 }\end{array}$ & $\begin{array}{c}\text { Reticulitermes } \\
\text { speratus (Kolbe), }\end{array}$ & \multirow[b]{2}{*}{ Termites } & \multirow[b]{2}{*}{$\begin{array}{l}\text { Recycling of uric } \\
\text { acid nitrogen }\end{array}$} & \multirow[b]{2}{*}{$\begin{array}{l}\text { Thong-On et } \\
\text { al. } 2012\end{array}$} \\
\hline & $\begin{array}{l}\text { AB673458 } \\
\text { AB673456 }\end{array}$ & $\begin{array}{c}\text { Glyptotermes } \\
\text { fuscus (Oshima), } \\
\text { Cryptotermes } \\
\text { domesticus } \\
\text { (Haviland) }\end{array}$ & & & \\
\hline E. sp. & $\begin{array}{l}\text { AY847157 } \\
\text { AY847162 }\end{array}$ & $\begin{array}{l}\text { Ceratitis capitata } \\
\text { (Wiedemann) }\end{array}$ & $\begin{array}{l}\text { Mediterra- } \\
\text { nean fruit } \\
\text { fly }\end{array}$ & Nitrogen-fixing & $\begin{array}{l}\text { Behar et al. } \\
\quad 2005\end{array}$ \\
\hline $\begin{array}{c}\text { E. } \\
\text { hormaechei }\end{array}$ & KC759162 & $\begin{array}{l}\text { Reticulitermes } \\
\text { chinensis } \\
\text { (Snyder) }\end{array}$ & Termite & $\begin{array}{l}\text { Lignin } \\
\text { degradation }\end{array}$ & $\begin{array}{l}\text { Zhou et al. } \\
2017\end{array}$ \\
\hline \multirow{2}{*}{ E. sp. } & JQ864378 & \multirow{2}{*}{$\begin{array}{l}\text { Reticulitermes } \\
\text { chinensis } \\
\text { (Snyder) }\end{array}$} & \multirow{2}{*}{ Termite } & \multirow{2}{*}{$\begin{array}{l}\text { Recycling of uric } \\
\text { acid nitrogen }\end{array}$} & \multirow{2}{*}{$\begin{array}{l}\text { Fang et al. } \\
\quad 2016\end{array}$} \\
\hline & JX291546 & & & & \\
\hline $\begin{array}{c}\text { E. } \\
\text { aerogenes }\end{array}$ & $\begin{array}{c}\text { Not } \\
\text { available }\end{array}$ & $\begin{array}{c}\text { Mastotermes } \\
\text { darwiniensis } \\
\text { Froggatt }\end{array}$ & \multirow{2}{*}{ Termite } & \multirow{2}{*}{$\begin{array}{c}\text { Lignin } \\
\text { degradation }\end{array}$} & \multirow{2}{*}{$\begin{array}{l}\text { Kuhnigk et } \\
\text { al. } 1994\end{array}$} \\
\hline $\begin{array}{c}E \\
\text { cloacae }\end{array}$ & $\begin{array}{c}\text { Not } \\
\text { available }\end{array}$ & $\begin{array}{l}\text { Reticulitermes } \\
\text { flavipes (Kollar) }\end{array}$ & & & \\
\hline
\end{tabular}




\begin{tabular}{|c|c|c|c|c|c|}
\hline $\begin{array}{c}\text { E. } \\
\text { aerogenes }\end{array}$ & $\begin{array}{c}\text { Not } \\
\text { available }\end{array}$ & $\begin{array}{c}\text { Mastotermes } \\
\text { darwiniensis } \\
\text { Froggatt }\end{array}$ & \multirow{2}{*}{ Termites } & \multirow{2}{*}{$\begin{array}{l}\text { Hemicellulose } \\
\text { degradation }\end{array}$} & \multirow{2}{*}{$\begin{array}{c}\text { Schäfer et al. } \\
1996\end{array}$} \\
\hline $\begin{array}{c}\text { E. } \\
\text { sakazaki }\end{array}$ & $\begin{array}{c}\text { Not } \\
\text { available }\end{array}$ & $\begin{array}{l}\text { Reticulitermes } \\
\text { flavipes (Kollar) }\end{array}$ & & & \\
\hline $\begin{array}{c}\text { E. } \\
\text { aerogenes }\end{array}$ & $\begin{array}{c}\text { Not } \\
\text { available }\end{array}$ & \multirow{2}{*}{$\begin{array}{l}\text { Coptotermes } \\
\text { formosanus } \\
\text { Shiraki }\end{array}$} & \multirow{2}{*}{$\begin{array}{c}\text { Formosan } \\
\text { subterra- } \\
\text { nean } \\
\text { termite }\end{array}$} & \multirow{2}{*}{$\begin{array}{l}\text { Cellulose/Hemi- } \\
\text { cellulose } \\
\text { degradation }\end{array}$} & \multirow{2}{*}{$\begin{array}{l}\text { Adams and } \\
\text { Boopathy } \\
2005\end{array}$} \\
\hline $\begin{array}{c}E . \\
\text { cloacae }\end{array}$ & $\begin{array}{c}\text { Not } \\
\text { available }\end{array}$ & & & & \\
\hline $\begin{array}{c}\text { E. } \\
\text { aerogenes }\end{array}$ & EU305608 & \multirow{2}{*}{$\begin{array}{c}\text { Coptotermes } \\
\text { curvignathus } \\
\text { (Holmgren) }\end{array}$} & \multirow{2}{*}{ Termite } & \multirow{2}{*}{$\begin{array}{l}\text { Lignocellulose } \\
\text { degradation }\end{array}$} & \multirow{2}{*}{$\begin{array}{l}\text { Ramin et al. } \\
\quad 2008\end{array}$} \\
\hline $\begin{array}{c}E \\
\text { cloacae }\end{array}$ & EU305609 & & & & \\
\hline $\begin{array}{c}E . \\
\text { cloacae }\end{array}$ & MF185378 & $\begin{array}{l}\text { Rhynchophorus } \\
\text { ferrugineus } \\
\text { (Olivier) }\end{array}$ & $\begin{array}{l}\text { Red palm } \\
\text { weevil }\end{array}$ & $\begin{array}{l}\text { Cellulose } \\
\text { degradation }\end{array}$ & $\begin{array}{l}\text { Muhammad } \\
\text { et al. } 2017\end{array}$ \\
\hline E. sp. & JN167548 & $\begin{array}{l}\text { Rhynchophorus } \\
\text { ferrugineus } \\
\text { (Olivier) }\end{array}$ & $\begin{array}{l}\text { Red palm } \\
\text { weevil }\end{array}$ & $\begin{array}{c}\text { Cellulose/Hemi- } \\
\text { cellulose } \\
\text { degradation }\end{array}$ & $\begin{array}{l}\text { Butera et al. } \\
\quad 2012\end{array}$ \\
\hline E. sp. & LN829595 & Coleoptera & $\begin{array}{l}\text { Wood- } \\
\text { feeding } \\
\text { beetle } \\
\text { larvae }\end{array}$ & $\begin{array}{l}\text { Lignocellulose } \\
\text { degradation }\end{array}$ & $\begin{array}{l}\text { Manfredi et } \\
\text { al. } 2015\end{array}$ \\
\hline \multirow[b]{2}{*}{ E. sp. } & HM771088 & $\begin{array}{c}\text { Cerambycidae, } \\
\text { Elateridae, }\end{array}$ & \multirow[b]{2}{*}{$\begin{array}{l}\text { Coleoptera } \\
\text { larvae }\end{array}$} & \multirow[b]{2}{*}{$\begin{array}{l}\text { Cellulose/Hemi- } \\
\text { cellulose } \\
\text { degradation }\end{array}$} & \multirow[b]{2}{*}{$\begin{array}{c}\text { Rojas- } \\
\text { Jiménez and } \\
\text { Hernández } \\
2015\end{array}$} \\
\hline & $\begin{array}{l}\text { HM771065 } \\
\text { HM771070 } \\
\text { HM771068 } \\
\text { HM771104 } \\
\text { HM771106 } \\
\text { HM771101 } \\
\text { HM771061 } \\
\text { HM771048 } \\
\text { GU827537 }\end{array}$ & $\begin{array}{c}\text { Passalidae and } \\
\text { Scarabaeidae }\end{array}$ & & & \\
\hline E. sp. & $\begin{array}{l}\text { HM235482 } \\
\text { HM235485 } \\
\text { HM235491 } \\
\text { HM235497 }\end{array}$ & $\begin{array}{l}\text { Sirex noctilio } \\
\text { Fabricius }\end{array}$ & $\begin{array}{l}\text { Wood- } \\
\text { feeding } \\
\text { wasp }\end{array}$ & $\begin{array}{l}\text { Cellulose } \\
\text { degradation }\end{array}$ & $\begin{array}{l}\text { Adams et al. } \\
2011\end{array}$ \\
\hline $\begin{array}{c}\text { E. } \\
\text { asburiae, } \\
\text { E. } \\
\text { cloacae, } \\
\text { E. sp. }\end{array}$ & $\begin{array}{l}\text { KT957438- } \\
\quad 43\end{array}$ & $\begin{array}{l}\text { Plutella xylostella } \\
\text { (Linnaeus) }\end{array}$ & $\begin{array}{l}\text { Diamond- } \\
\text { back moth }\end{array}$ & $\begin{array}{c}\text { Cellulose/Hemi- } \\
\text { cellulose } \\
\text { degradation }\end{array}$ & $\begin{array}{c}\text { Xia et al. } \\
2017\end{array}$ \\
\hline E. sp. & $\begin{array}{c}\text { Not } \\
\text { available }\end{array}$ & $\begin{array}{c}\text { Diestrammena } \\
\text { asynamora } \\
\text { (Adelung) }\end{array}$ & $\begin{array}{c}\text { Greenhouse } \\
\text { camel } \\
\text { cricket }\end{array}$ & $\begin{array}{c}\text { Cellulose/Hemi- } \\
\text { cellulose } \\
\text { degradation }\end{array}$ & $\begin{array}{l}\text { Mathews et } \\
\text { al. } 2019\end{array}$ \\
\hline E. sp. & $\begin{array}{c}\mathrm{AB} 872360 \\
-384\end{array}$ & $\begin{array}{c}\text { Holotrichia } \\
\text { parallela } \\
\text { (Motschulsky) }\end{array}$ & $\begin{array}{c}\text { Dark black } \\
\text { chafer } \\
\text { beetle }\end{array}$ & $\begin{array}{l}\text { Cellulose/Hemi- } \\
\text { cellulose } \\
\text { degradation }\end{array}$ & $\begin{array}{l}\text { Sheng et al. } \\
2015\end{array}$ \\
\hline E. cloacae & $\begin{array}{c}\text { Not } \\
\text { available }\end{array}$ & $\begin{array}{c}\text { Coptotermes } \\
\text { curvignathus } \\
\text { (Holmgren) }\end{array}$ & Termite & $\begin{array}{l}\text { Cellulose } \\
\text { degradation }\end{array}$ & $\begin{array}{c}\text { Toczyłowsk } \\
\text { a-Mamińska } \\
\text { et al. } 2015\end{array}$ \\
\hline E. cloacae & KC512248 & $\begin{array}{c}\text { Plutella xylostella } \\
\text { (Linnaeus) }\end{array}$ & $\begin{array}{l}\text { Diamond- } \\
\text { back moth }\end{array}$ & $\begin{array}{l}\text { Trehalose } \\
\text { hydrolysis }\end{array}$ & $\begin{array}{l}\text { Adhav et al. } \\
2019\end{array}$ \\
\hline
\end{tabular}




\begin{tabular}{|c|c|c|c|c|c|}
\hline E. cloacae & $\begin{array}{c}\text { Not } \\
\text { available }\end{array}$ & $\begin{array}{c}\text { Thermobia } \\
\text { domestica } \\
\text { (Packard) }\end{array}$ & Firebrat & $\begin{array}{l}\text { Water and } \\
\text { nutrients }\end{array}$ & $\begin{array}{c}\text { Woodbury } \\
\text { and Gries } \\
2013 a, b\end{array}$ \\
\hline \multirow{2}{*}{ E. sp. } & $\begin{array}{c}\text { LJAN0100 } \\
0071\end{array}$ & \multirow{2}{*}{$\begin{array}{c}\text { Bactrocera oleae } \\
\text { (Rossi) }\end{array}$} & \multirow{2}{*}{$\begin{array}{l}\text { Olive fruit } \\
\text { fly }\end{array}$} & \multirow{2}{*}{$\begin{array}{c}\text { Amino acids and } \\
\text { vitamins }\end{array}$} & \multirow{2}{*}{$\begin{array}{c}\text { Estes et al. } \\
2018 \mathrm{a}\end{array}$} \\
\hline & $\begin{array}{l}\text { locus_taq:A } \\
\text { C520_4801 }\end{array}$ & & & & \\
\hline E. sp. & KR232642 & $\begin{array}{c}\text { Ceratitis capitata } \\
\text { (Wiedemann) }\end{array}$ & $\begin{array}{c}\text { Mediterra- } \\
\text { nean fruit } \\
\text { fly }\end{array}$ & Probiotic & $\begin{array}{c}\text { Augustinos } \\
\text { et al. } 2015\end{array}$ \\
\hline \multirow{2}{*}{$\begin{array}{c}\text { E. } \\
\text { cloacae, } \\
\text { E. } \\
\text { asburiae }\end{array}$} & KY810513 & \multirow{2}{*}{$\begin{array}{l}\text { Ceratitis capitata } \\
\text { (Wiedemann) }\end{array}$} & \multirow{2}{*}{$\begin{array}{l}\text { Mediterra- } \\
\text { nean fruit } \\
\text { fly }\end{array}$} & \multirow{2}{*}{ Probiotic } & \multirow{2}{*}{$\begin{array}{c}\text { Hamden et } \\
\text { al. } 2013\end{array}$} \\
\hline & KY810514 & & & & \\
\hline $\begin{array}{c}\text { E.agglome- } \\
\text { rans }\end{array}$ & $\begin{array}{c}\text { Not } \\
\text { available }\end{array}$ & $\begin{array}{l}\text { Ceratitis capitata } \\
\text { (Wiedemann) }\end{array}$ & $\begin{array}{l}\text { Mediterra- } \\
\text { nean fruit } \\
\text { fly }\end{array}$ & Probiotic & $\begin{array}{c}\text { Niyazi et al. } \\
2004\end{array}$ \\
\hline E. sp. & $\begin{array}{c}\text { Not } \\
\text { available }\end{array}$ & $\begin{array}{c}\text { Zeugodacus } \\
\text { cucurbitae } \\
\text { (Coquillett) }\end{array}$ & Melon fly & Probiotic & $\begin{array}{l}\text { Yao et al. } \\
2017\end{array}$ \\
\hline $\begin{array}{c}\text { E. } \\
\text { sakazakii }\end{array}$ & $\begin{array}{c}\text { DQ228421- } \\
22\end{array}$ & $\begin{array}{l}\text { Stomoxys } \\
\text { calcitrans } \\
\text { Linnaeus }\end{array}$ & Stable fly & Probiotic & $\begin{array}{c}\text { Mramba et } \\
\text { al. } 2007\end{array}$ \\
\hline $\begin{array}{c}\text { E. } \\
\text { cloacae }\end{array}$ & $\begin{array}{c}\text { Not } \\
\text { available }\end{array}$ & $\begin{array}{l}\text { Plutella xylostella } \\
\text { (Linnaeus) }\end{array}$ & $\begin{array}{l}\text { Diamond- } \\
\text { back moth }\end{array}$ & Probiotic & $\begin{array}{l}\text { Somerville } \\
\text { et al. } 2019\end{array}$ \\
\hline
\end{tabular}

\subsubsection{Nitrogen Fixation}

A well-established contribution of Enterobacter species to nutrition is nitrogen fixation. Nitrogen fixation is a metabolic capability that is absent from the ancestral eukaryote and has been acquired by multiple eukaryotic groups through symbiosis. Many insects are known to live on low nitrogen diets, and microorganisms have been suggested to provide availability of these essential foodstuffs in various ways (Douglas 2009).

Potrikus and Breznak (1977) identified two Enterobacter agglomerans strains from the guts of Formosan subterranean termites (Coptotermes formosanus). Nitrogen fixation appears to play an essential role in termite biology by helping them overcome deficiencies related to their nitrogen-poor diet (wood). The process was found to be linked to the termite gut bacteria since antibiotic treatment eliminated the function (Breznak et al. 1973). Strains C-1 and C-2 were characterized with electron microscopy and numerous biochemical assays, including sugar fermentation tests. The nitrogen-fixing ability of the strains was verified with acetylene reduction tests, in both aerobic and anaerobic $\left(100 \% \mathrm{~N}_{2}\right.$ or $\left.100 \% \mathrm{Ar}\right)$ growing conditions, using different sources of nitrogen (peptone, $\mathrm{NH}_{4} \mathrm{Cl}, \mathrm{KNO}_{3}$ ). In media lacking peptone, $\mathrm{NH}_{4} \mathrm{Cl}$ or $\mathrm{KNO}_{3}$, nitrogen fixation by both strains occurred only under anaerobic conditions when $100 \% \mathrm{~N}_{2}$ was provided. When peptone, $\mathrm{NH}_{4} \mathrm{Cl}$, or $\mathrm{KNO}_{3}$ was provided in the media, fixation was taking place in both aerobic and anaerobic conditions (Potrikus and Breznak 1977). 
Nitrogen fixation by Enterobacter species was also identified in the gut of termite species from Australia (in seven out of nine species tested) (Eutick et al. 1978). The Enterobacter strains could grow on nitrogen-free media under anaerobic conditions, but also under aerobic conditions in the presence of $\mathrm{H}_{2} \mathrm{SO}_{4}$ (Eutick et al. 1978).

Some years later, nitrogen-fixing Enterobacter agglomerans and Enterobacter spp. were isolated from various species of bark beetles, including Dendroctonus terebrans, D. frontalis and Ips avulsus (Bridges 1981). Even though large populations of nitrogen-fixing bacteria were found in the beetles, the in-situ assays in larvae did not reveal any acetylene reduction (Bridges 1981).

In the wood-boring beetle Anoplophora chinensis, enrichment studies of adult gut homogenates for nitrogen-fixing revealed the presence of four Enterobacter strains (Rizzi et al. 2013). The adult insects used in the enrichment cultures were isolated from Acer saccharinum L. and Alnus host trees (Rizzi et al. 2013).

Many microorganisms are valuable to the insect for their more comprehensive metabolic capabilities, including their capacity to utilize insect nitrogenous waste compounds (e.g. uric acid), synthesize 'high value' nitrogenous compounds (e.g. essential amino acids) and fix nitrogen (Douglas 2009). Uric acid is another substance utilized as a nitrogen source in insects feeding on nitrogen-poor diets composed of plant material (Potrikus and Breznak 1981). In such a case, four uricolytic Enterobacter strains were isolated from the guts of three wood-feeding termite species (Reticulitermes speratus, Glyptotermes fuscus and Cryptotermes domesticus) (ThongOn et al. 2012). Bacteria with uricolytic activity were grown anaerobically on plates containing various concentrations of uric acid. Isolated strains, RsN-1, GfU-1, Cd20b and Cd15a, showed $>98 \%$ identity with Enterobacter amnigenus, E. aerogenes, E. asburiae and E. cowanii, respectively (Thong-On et al. 2012).

Enterobacter cloacae strains isolated from field-collected, and laboratory-reared Bactrocera tryoni (Froggatt) fruit flies showed dinitrogenase activity and were able to fix atmospheric nitrogen (Drew and Lloyd 1987; Murphy et al. 1994). Diazotrophic Enterobacter strains were also isolated from gut tissue of field-collected Mediterranean fruit flies Ceratitis capitata (Behar et al. 2005; Augustinos et al. 2021). However, the most potent nitrogen-fixing effect was produced by Klebsiella and Citrobacter species. Nitrogen fixation activity was estimated by a variety of methods, including acetylene reduction assays in live flies and bacteria grown on nitrogendeficient media, amplification of the nitrogenase iron protein gene ( $\mathrm{nifH}$ ) from gut extracts and isolated colonies, as well as in situ expression and amplification of the nifH gene (Behar et al. 2005).

\subsubsection{Degradation of Plant Cell Wall Components}

Various Enterobacter strains are also able to provide nutrients to insects through the degradation of plant cell wall components (lignin, cellulose, hemicellulose) (König et al. 2006). Lignocellulolytic Enterobacter species have been identified in plant or wood-feeding insects, like beetles, termites or wasps. 
A ligninolytic Enterobacter strain was isolated from abdomens of adult Reticulitermes chinensis termites that use the plant cell wall polysaccharide in their diet (Zhou et al. 2017). Strain PY12, classified as E. hormaechei based on its $16 \mathrm{~S}$ rRNA sequence, produced a lignin-modifying peroxidase (LiP), a key component in the lignin degradation pathway (Zhou et al. 2017; Janusz et al. 2017). The decolourization of six different dyes determined Lip activity by spectrophotometry. Since the study focused only on one of the ligninolytic enzymes in the pathway, it was not entirely possible to elucidate how strain PY12 contributes to lignin degradation and the possible synergies it develops (Zhou et al. 2017).

Seven Enterobacter strains with the ability to degrade lignin and related aromatic compounds were identified in hindguts of various laboratory-reared and fieldcollected species of termites (Kuhnigk et al. 1994). Degradation was observed under aerobic conditions, while in the absence of oxygen, only slight modifications of the side group of aromatic compounds occurred (Kuhnigk et al. 1994). The strains were characterized as E. aerogenes (Km3 and KAn8), E. cloacae (Rt5a, Rt5b and Rt5c) and Enterobacter sp. (Rt3a and Rt3b). The first two were isolated from Mastotermes darwiniensis and the remaining five from Reticulitermes flavipes termites. Among the seven strains, Km3 and KAn8 exhibited the most significant degradation potential, with the ability to degrade nine out of 13 substrates tested (Kuhnigk et al. 1994). Apart from degrading lignin, strain $\mathrm{Km} 3$ also showed hemicellulose degrading activity (Schäfer et al. 1996). Hemicellulose was also degraded by Enterobacter sakazakii strain RA2 that was isolated from hindguts of wild $R$. flavipes termites from France (Schäfer et al. 1996). Interestingly, strain RA2 exhibited all (four out of four) enzyme activities that were tested and were related to polysaccharide degradation. On the other hand, strain Km3 lacked 1,4- $\beta$-xylanase activity (Schäfer et al. 1996). In a particular environment, though, bacteria lacking members of the metabolic cascade could act synergistically with other strains present to fully degrade substances.

The Formosan subterranean termite, C. formosanus contained E. aerogenes and E. cloacae strains that effectively utilized xylose as a carbon source (Adams and Boopathy 2005). Two strains isolated from Coptotermes curvignathus termites from Malaysia and identified as E. aerogenes and E. cloacae were able to degrade carboxymethylcellulose (CMC) and cellobiose (Ramin et al. 2008). Other lignocellulolytic strains identified in higher and lower termites belonged to the species E. aerogenes, E. agglomerans and E. cloacae (König et al. 2006; Mannesmann and Piechowski 1989).

\subsubsection{Degradation and Biosynthesis of Other Nutrients}

In the diamondback moth Plutella xylostella, Adhav et al. (2019) characterized, structurally and biochemically, a trehalase from Enterobacter cloacae which assists in the hydrolysis of trehalose, a significant energy source in insect metabolism. Firebrat nymphs (Thermobia domestica) acquire water and nutrients by consuming Enterobacter cloacae, facilitating their growth and survival in the absence of food or water for up to 22 days (Woodbury and Gries 2013a,b). 
Genome sequencing of Enterobacter sp. OLF (Table 3), isolated from wild California olive fruit flies, revealed genes related to the biosynthesis of amino acids, vitamins and co-factors, degradation pathways, nitrogen metabolism, as well as the production of energy and precursor metabolites (Estes et al. 2018a, 2018b).

This characterization could mean that the strain could potentially supply its host, in cooperation with other symbionts, with amino acids, vitamins or other nutritional compounds missing from the olive fruit diet (Estes et al. 2018a, 2018b).

Table 3. Available genome sequences of Enterobacter symbionts from insects

\begin{tabular}{|c|c|c|c|c|}
\hline $\begin{array}{l}\text { Accession } \\
\text { number }\end{array}$ & $\begin{array}{l}\text { Enterobacter } \\
\text { Strain }\end{array}$ & Host & Status & $\begin{array}{c}\text { Submission } \\
\text { Date }\end{array}$ \\
\hline PRJNA420145 & $\begin{array}{l}\text { E. cancerogenus } \\
\text { CR-Eb1 }\end{array}$ & $\begin{array}{l}\text { Galleria mellonella } \\
\text { (Linnaeus) }\end{array}$ & complete & 2018 \\
\hline PRJNA288712 & E. sp. OLF & Bactrocera oleae (Rossi) & complete & 2018 \\
\hline PRJNA340971 & E. Larv1_ips & $\begin{array}{l}\text { Ips typographus } \\
\text { (Linnaeus) }\end{array}$ & draft & 2019 \\
\hline PRJNA390046 & E. sp. $10-1$ & Cerambycidae & draft & 2017 \\
\hline PRJNA364290 & E. JKSO00234 & Formicidae & draft & 2017 \\
\hline PRJNA364289 & E. JKSO00233 & Formicidae & draft & 2017 \\
\hline PRJNA179500 & E. hormaechei YT2 & $\begin{array}{l}\text { Tenebrio molitor } \\
\text { (Linnaeus) }\end{array}$ & draft & 2012 \\
\hline PRJNA180991 & E. hormaechei YT3 & $\begin{array}{l}\text { Zophobas morio } \\
\text { Fabricius }\end{array}$ & draft & 2013 \\
\hline PRJNA180988 & $\begin{array}{l}\text { E. cancerogenus } \\
\mathrm{YZ1}\end{array}$ & $\begin{array}{l}\text { Tenebrio molitor } \\
\text { (Linnaeus) }\end{array}$ & draft & 2013 \\
\hline PRJNA169065 & E. sp. Ag1 & $\begin{array}{l}\text { Anopheles gambiae } \\
\text { Giles }\end{array}$ & draft & 2012 \\
\hline
\end{tabular}

\subsubsection{Probiotic Effects of Enterobacter}

The most recent contribution of Enterobacter strains to insect fitness and nutrition is their emerging role as probiotics in diets of mass-reared C. capitata and Zeugodacus cucurbitae flies. Such properties can be particularly useful in Sterile Insect Technique (SIT) applications where irradiation treatment takes a heavy toll on insect competitiveness if the dose administered is high. In this regard, strains that were provided as probiotics in diets greatly improved various fitness parameters of the flies including pupal weight, longevity, adult size, flight ability, and adult emergence (Niyazi et al. 2004; Ben Ami et al. 2009; Hamden et al. 2013; Yuval et al. 2013; Augustinos et al. 2015, 2021; Kyritsis et al. 2017; Yao et al. 2017; Cáceres et al. 2019). For example, the provision of Enterobacter sp. strain AA26 resulted in increased production of pupae and adults, as well as reduced rearing duration in various developmental stages (from egg to pupa, pupal stage and from egg to adult), particularly for male $C$. capitata flies (Augustinos et al. 2015). However, it did not affect pupal weight, sex ratio, male mating competitiveness, flight ability or life span under food and water deprivation (Augustinos et al. 2015; Kyritsis et al. 2017). 
Hamden et al. (2013) on the other hand observed increased pupal weight, male sexual performance and survival rates under food deprivation when they enriched the larval diet of mass-reared C. capitata with Enterobacter sp. and other beneficial bacteria (Klebsiella pneumoniae and Citrobacter freundii). In terms of mating competitiveness, irradiated males reared on probiotics achieved more matings and transferred larger quantities of sperm to females. Finally, in addition to pupal weight, probiotics also resulted in increased body size for adult males (head width, abdomen and thorax length) (Hamden et al. 2013). Niyazi et al. observed a diet-dependent probiotic effect on the mate-calling activity, mating success, life expectancy, and survival of mass-reared male C. capitata flies (Niyazi et al. 2004). The probiotic effect of E. agglomerans and K. pneumoniae on each of these parameters differed among the four diets that were tested (two standard adult diets and two enhanced experimental formulations), ranging from significant to non-existent (Niyazi et al. 2004). Differences in the probiotic effect were also observed between the laboratory trials and the field-cage assay (Niyazi et al. 2004).

Similarly, Yao et al. (2017) tested gut-associated Enterobacter spp. as probiotics in the larval diet of irradiated laboratory-reared Z. cucurbitae flies. Both live and autoclaved bacteria were tested to distinguish between insect-bacteria interactions and plain nutritional value of the probiotic effect. Application of the live bacteria increased female and male pupal weight, various morphological traits of adult flies, including head width and thorax length, as well as survival (Yao et al. 2017). In the case of survival rate, autoclaved bacteria resulted in a greater increase compared to live bacteria (Yao et al. 2017).

Mramba and colleagues studied the effects of E. sakazakii on stable fly Stomoxys calcitrans development (Mramba et al. 2007). They observed that sterile media did not support any fly development and that the effect was reversed with the addition of E. sakazakii. However, an improved effect for fly development was mainly observed in cooperation with other microbial partners in non-sterilized media. The combination of non-sterile media and E. sakazakii resulted in a slight increase in the survival of larvae to the pupal stage, in pupal weight and adult emergence and also displayed increased duration of the larval and pupal stages compared to the non-sterile media without the inoculum with E. sakazakii (Mramba et al. 2007).

A similar probiotic effect was observed in transgenic diamondback moth larvae (Somerville et al. 2019). The larvae that were grown on an aseptic diet (sterile diet and addition of streptomycin) and were inoculated with streptomycin-resistant $E$. cloacae JJBC exhibited increased pupal weight and production of progeny compared to an aseptic diet without the inoculum (Somerville et al. 2019).

In Apis mellifera jemenitica Ruttner, however, the E. kobei strain that was examined for its probiotic effect did not manage to reduce mortality of bee larvae infected with Paenibacillus spores (Al-Ghamdi et al. 2018).

\subsection{Enterobacter and Protective Functions}

Insects live in close coalition with microorganisms, which immensely influence their ecology and evolution. Microorganisms, such as bacteria, archaea, fungi, protozoa, viruses, can be associated with their insect host permanently or transiently, and such 
associations may be beneficial or harmful to the insects' fitness (Gurung et al. 2019). For instance, endosymbionts tend to be dependent on the hosts for obtaining nutrients, whereas they can provide fitness advantages in terms of nutritional components (see above), overcoming host defences, and protection from pathogens, parasites, or environmental stressors (Engel and Moran 2013; Mereghetti et al. 2017).

The insect microbiota are also able to provide protective functions to their hosts, thereby influencing the proliferation of important human or animal pathogens (Table 4), including Plasmodium, Trypanosoma, dengue, Zika, yellow fever or chikungunya viruses, inside the insect body with a variety of mechanisms, either indirectly, by causing innate responses of the insect immune system or directly, through competition for resources with the pathogen or the production of substances with anti-pathogenic effects (Dong et al. 2009; Moreira et al. 2009; Bian et al. 2010, 2013; Cirimotich et al. 2011b; Walker et al. 2011; Weiss and Aksoy 2011; van den Hurk et al. 2012; Zhang et al. 2013; Dennison et al. 2014; Frentiu et al. 2014; Aliota et al. 2016a, 2016b; Dutra et al. 2016; Tan et al. 2017; Kalappa et al. 2018).

Table 4. Enterobacter species can provide protective functions to their hosts, aiding them to cope with abiotic and biotic stress

\begin{tabular}{|c|c|c|c|}
\hline $\begin{array}{l}\text { Enterobacter } \\
\text { Species }\end{array}$ & Strain Accession Number & \multicolumn{2}{|l|}{ Host } \\
\hline Enterobacter $\mathrm{sp}$. & JF690924 & Anopheles arabiensis Patton & Mosquito \\
\hline Enterobacter cloacae & Not available & Anopheles stephensi Liston & Mosquito \\
\hline Enterobacter $s p$. & JQ680715 & Anopheles gambiae Giles & Mosquito \\
\hline $\begin{array}{l}\text { Enterobacter cloacae, } \\
\text { Enterobacter } \\
\text { amnigenus }\end{array}$ & Not available & $\begin{array}{l}\text { Anopheles albimanus } \\
\text { Wiedemann }\end{array}$ & Mosquito \\
\hline Enterobacter ludwigii & MF084966 MF084975 & Delia antiqua (Meigen) & Onion fly \\
\hline Enterobacter sp. & EU693561 EU693573 & $\begin{array}{l}\text { Leptinotarsa decemlineata } \\
\text { Say }\end{array}$ & $\begin{array}{l}\text { Colorado potato } \\
\text { beetle }\end{array}$ \\
\hline $\begin{array}{l}\text { Enterobacter ludwigii, } \\
\text { Enterobacter asburiae }\end{array}$ & $\begin{array}{l}\text { KX398658 KX398648 } \\
\text { KX398650 KX398654 } \\
\text { KX398657 }\end{array}$ & Helicoverpa zea (Boddie) & Corn earworm \\
\hline $\begin{array}{l}\text { Enterobacter } \\
\text { agglomerans }\end{array}$ & Not available & $\begin{array}{l}\text { Rhagoletis pomonella } \\
\text { (Walsh) }\end{array}$ & Apple maggot fly \\
\hline $\begin{array}{l}\text { Enterobacter asburiae, } \\
\text { Enterobacter cloacae, } \\
\text { Enterobacter } \text { sp. }\end{array}$ & $\begin{array}{l}\text { KT957438 KT957439 } \\
\text { KT957440 KT957441 } \\
\text { KT957442 KT957443 }\end{array}$ & Plutella xylostella (Linnaeus) & $\begin{array}{l}\text { Diamondback } \\
\text { moth }\end{array}$ \\
\hline Enterobacter sp. & KX117074 & Leptinotarsa juncta Germar & $\begin{array}{l}\text { False potato } \\
\text { beetle }\end{array}$ \\
\hline Enterobacter sp. & JX296530 KC977257 & $\begin{array}{l}\text { Leptinotarsa decemlineata } \\
\text { Say }\end{array}$ & $\begin{array}{l}\text { Colorado potato } \\
\text { beetle }\end{array}$ \\
\hline Enterobacter cloacae & $\begin{array}{l}\text { KM878728 KM886372 } \\
\text { KM878717 }\end{array}$ & $\begin{array}{l}\text { Coptotermes formosanus } \\
\text { Shiraki }\end{array}$ & $\begin{array}{l}\text { Formosan } \\
\text { subterranean } \\
\text { termite }\end{array}$ \\
\hline Enterobacter cloacae & Not available & $\begin{array}{l}\text { Glyphodes duplicalis Inoue et } \\
\text { al. }\end{array}$ & Mulberry pyralid \\
\hline $\begin{array}{l}\text { Enterobacter } \\
\text { amnigenus }\end{array}$ & Not available & $\begin{array}{l}\text { Anopheles dirus Peyton \& } \\
\text { Harrison }\end{array}$ & Mosquito \\
\hline
\end{tabular}


These effects continuously draw attention as a means of controlling vector-based infectious diseases, like malaria or dengue virus, that are transmitted by Anopheles and Aedes mosquito vectors (Cirimotich et al. 2011a; Jayakrishnan et al. 2018; Saldaña et al. 2017).

\subsubsection{Enterobacter Anti-pathogenic Effects in Mosquitoes}

Among various bacterial strains that show anti-pathogenic effects, one of the best characterized is Enterobacter strain Esp_Z, which was isolated from the midgut of wild Anopheles arabiensis mosquitoes in Zambian populations. The Enterobacter strain inhibited Plasmodium development in the midgut by $98 \%, 99 \%$ and $99 \%$ before the ookinete, oocyst, and sporozoite stage respectively (Cirimotich et al. 2011c). This response proved to be independent of the mosquito immune system since antiPlasmodium genes, that are usually triggered during Plasmodium infections, showed similar activity in mosquitoes infected with $E s p \_Z$ or with non-inhibitory bacteria.

Additionally, silencing of anti-Plasmodium genes with RNAi in mosquitoes infected with Esp_Z did not result in Plasmodium oocyst development (Cirimotich et al. 2011c). The response also proved to be independent of bacterial retention of mosquito factors that are essential for Plasmodium development like, xanthurenic acid, iron and substances involved in fatty acid metabolism. Moreover, the inhibition effect was dose-dependent, both in vitro and in vivo conditions, with $10^{4}$ bacterial cells providing near-complete protection against parasite infection and coinciding with active bacteria replication (Cirimotich et al. 2011c).

In view of the above, the inhibition activity was therefore hypothesized to be the result of anti-pathogenic substances. Indeed, the Enterobacter strain was found to produce Plasmodium-killing (Luckhart et al. 1998; Kumar et al. 2003; Peterson et al. 2007; Molina-Cruz et al. 2008) reactive oxygen species (Cirimotich et al. 2011c). These molecules were not detected in non-inhibitory bacteria, and their effect was neutralized by antioxidants in Esp_Z-containing insects, such as vitamin $\mathrm{C}$ and glutathione (Cirimotich et al. 2011c).

On the other hand, Eappen et al. (2013) identified Enterobacter cloacae strains that inhibited Plasmodium development by activating a component of the immune system of Anopheles stephensi mosquitoes. More specifically, E. cloacae was able to induce the expression of a serine protease inhibitor (SRPN6) in the mosquito midgut. The effect was linked to bacteria that were acquired through feeding and were exposed to the luminal side of the midgut epithelium, whereas bacteria injected in the haemocoel and exposed to the basal surface of the midgut epithelium were incapable of SRPN6 induction (Eappen et al. 2013). Unlike strain Esp_Z, the E. cloacae strains did not interfere with Plasmodium ookinete formation, but with the differentiation of ookinetes into oocysts after they traversed the midgut epithelium. Silencing of the SRPN6 gene resulted in an increase in the number of Plasmodium oocysts and increased prevalence of infection, implying that additional immune components are likely to participate in the inhibition process by E. cloacae (Eappen et al. 2013). 
In field-collected Anopheles gambiae mosquitoes from Cameroon, Enterobacter spp. bacteria isolated from their midgut reduced Plasmodium falciparum oocyst intensity and prevalence by $35 \%$ and $15 \%$, respectively. However, the reduction in infection was lower when parasite exposure was higher (Tchioffo et al. 2013).

Enterobacter bacteria that were isolated from the midgut of field-collected Anopheles albimanus mosquitoes in Mexico suppressed Plasmodium vivax infection in the insectary and field-collected samples (Gonzalez-Ceron et al. 2003). After seven days of treatment, E. cloacae and E. amnigenus 2 reduced Plasmodium infection by 17 and 53 times compared to control mosquitoes, respectively. Additionally, E. cloacae infected mosquitoes showed 2.5 times lower Plasmodium oocyst density than the controls (Gonzalez-Ceron et al. 2003).

\subsubsection{Enterobacter Effects in Herbivorous Insects}

Two Enterobacter ludwigii strains (B424 and B539) that were part of the natural gut microbiota of the onion fly Delia antiqua collected from garlic fields in China, showed inhibitory effects against Beauveria bassiana (Balsamo), an entomopathogenic fungus that is used as a biocontrol agent in pest management applications (Valero-Jiménez et al. 2014; Zhou et al. 2019). The vital role of the bacterial symbionts of $D$. antiqua on the larvicidal potential of $B$. bassiana, was determined by first examining axenic (bacteria-free) and non-axenic larvae infected with the fungus (Zhou et al. 2019). In this case, treatment with the pathogen did not affect the survival of non-axenic larvae but indicated a significant reduction in the survival of axenic larvae. Furthermore, axenic larvae inoculated with microbiota were characterized by significantly higher survival rates than non-inoculated axenic larvae, when both were infected with the fungus (Zhou et al. 2019). Following the above tests, symbiotic bacteria were isolated from the surface and guts of the onion fly, and certain strains were tested for their anti-fungal effect. The Enterobacter strains strongly inhibited (ca. 70-99\%) conidia germination and the hyphal growth of the entomopathogen fungus $B$. bassiana. Additionally, as expected from the previous tests, inoculation of axenic larvae with strain B424 significantly increased survival rate against the fungal infection (Zhou et al. 2019).

Similar observations were made with the Colorado potato beetle Leptinotarsa decemlineata fourth-instar larvae that were field-collected in Maryland and Virginia, USA (Blackburn et al. 2008). Enterobacter sp. strains 2B1C and 2B2D that were isolated from larval faecal fluid were found to inhibit two entomopathogens, Photorhabdus temperata Fischer-Le Saux et al. and the fungus B. bassiana. $P$. temperata is a bacterial symbiont of the entomopathogenic nematode Heterorhabditis marelatus Liu \& Berry which can be used to suppress the Colorado potato beetle. However, in the presence of the Enterobacter strains the nematode fails to complete its reproductive cycle in the beetle, possibly due to the inhibition of $P$. temperata (Armer et al. 2004). The in vitro tests were based on comparing on PP3 agar plates (Bacto ${ }^{\circledR}$ Proteose Peptone) the growth of $P$. temperata and $B$. bassiana conidia in the presence of each Enterobacter strain. Both strains reduced the growth of $P$. temperata by approximately $33 \%$ while at the same time, strain $2 \mathrm{~B} 1 \mathrm{C}$ and $2 \mathrm{~B} 2 \mathrm{D}$ reduced fungal growth by almost $80 \%$ and $42.5 \%$ respectively (Blackburn et al. 2008). 
Enterobacter strains have also been recognized as essential factors in shaping interactions between herbivorous insects and plants, by either activating or suppressing plant defences. In such a case of activation, laboratory-reared Helicoverpa zea larvae inoculated orally with an Enterobacter ludwigii strain were found to activate tomato plant Solanum lycopersicum defences (Wang et al. 2017). The strain was isolated from oral secretions, the regurgitant, of field-collected H. zea larvae in Rock Springs, Pennsylvania, USA. The E. ludwigii strain along with an $E$. asburiae strain were found to increase the activity of glucose oxidase (GOX), a molecular signal that induces plant defences in response to herbivory, in the labial glands of laboratory-reared larvae (Wang et al. 2017). Even though direct application of both strains on wounded tomato plants resulted in suppression of polyphenol oxidase (PPO) activity, a plant defence component which is regulated by jasmonic acid (JA), when tomato plants were damaged by E. ludwigii-inoculated larvae, they showed an increase in JA-regulated genes (proteinase inhibitor II (Pin2), cysteine proteinase inhibitor $(C y s P I)$ and polyphenol oxidase $\mathrm{F}(\mathrm{PPOF})$ ), and a suppression in salicylic acid (SA) response (pathogenesis-related protein 1 (P4), Prla (P4)). Suppression of JA-mediated response proved to be dose-dependent, with high bacteria concentrations producing significant results when applied directly on the plant.

In the diamondback moth, two Enterobacter species, E. asburiae and E. cloacae, encoded all the genes related to the aerobic pathway for catechol degradation and could significantly degrade phenol in vitro (Xia et al. 2017). These compounds are important plant defence compounds of Brassica plants as they are toxic to insects (Xia et al. 2017).

In a contrary case of suppressing plant defences, in antibiotic-treated laboratoryreared false potato beetle (Leptinotarsa juncta) larvae, Enterobacter inoculation reduced JA-regulated gene expression (PPO) in tomato leaves (non-preferred host, $S$. lycopersicum), but did not have any effect on horsenettle (preferred host, Solanum carolinense Linnaeus) (Wang et al. 2016). Damage to leaves by untreated false potato beetle larvae or application of their oral secretions to wounded leaves resulted in reduced PPO activity in both plants compared to antibiotic-treated larvae (Wang et al. 2016). Additionally, direct application of Enterobacter on wounded leaves suppressed JA-regulated PPO and CysPI expression and increased SA-regulated Prl expression in tomato, but not in horsenettle (Wang et al. 2016).

Similarly, Chung et al. (2013) observed that damage caused to tomato plants by antibiotic-treated Colorado potato beetle larvae increased JA-regulated gene expression $(C y s P I$ and $P P O F / B)$ and a decrease in the SA defence response ( $\operatorname{Pr} 1$ (P4)) compared to untreated larvae. Additionally, lower $P P O$ activity was observed when oral secretions of untreated larvae were applied on mechanically wounded plants. These observations suggested that bacteria in oral secretions of the Colorado potato beetle suppressed the JA-mediated defence mechanism. Indeed, an Enterobacter strain that was isolated from larval oral secretions suppressed JA-mediated antiherbivore defence response (PPO) in tomato plants when it was inoculated in antibiotic-treated Colorado potato beetle larvae (Chung et al. 2013). 


\section{BACTERIAL PARATRANSGENESIS WITH ENTEROBACTER}

As Enterobacter strains form extremely stable relations with insects by constituting a prevalent portion of their gut microbiota, they can function as vectors for the introduction of functional genes that could be useful for multiple applications, including pest population control (Wilke and Marrelli 2015).

Such a system was examined in Enterobacter cloacae species isolated from the guts of Formosan subterranean termites in Hawaii (Husseneder and Grace 2005). The bacteria were transformed with a recombinant plasmid containing genes encoding ampicillin resistance and green fluorescent protein (GFP) and were fed to termite workers from three colonies (Husseneder and Grace 2005). The infection was established rapidly, with $90-100 \%$ of termite workers containing transformed bacteria $12 \mathrm{~h}$ after feeding, which persisted in the population for up to 11 weeks. Moreover, fluorescent microscopy revealed that the ingested bacteria expressed the GFP gene in the termite gut. Transformed bacteria were efficiently transferred through a colony, with infection rates reaching $80-100 \%$ after six days, even when the initial ratio between infected and uninfected termites was low. Recombinant bacteria were also transferred into the soil by infected termites but declined rapidly within four to five weeks (Husseneder and Grace 2005).

In another example, Enterobacter cloacae strain WBMH-3-CM ${ }^{\mathrm{r}}$ was transformed with plasmids containing the ice nucleation gene inaA of Erwinia ananas IN10 and were ingested by larvae of mulberry pyralid Glyphodes duplicalis (Watanabe et al. 2000). Ice nucleation genes increase the supercooling points and reduce the tolerance of overwintering insects to cold, resulting in death by freezing. The supercooling points of mulberry pyralid larvae treated with the transgenic E. cloacae strain were higher than E. ananas-treated larvae, and their mortality rate reached $64.3 \%$ after $2 \mathrm{~h}$ exposure at $-5^{\circ} \mathrm{C}$ and eventually increased to $95.2-100 \%$ after 6 and $18 \mathrm{~h}$ of exposure (Watanabe et al. 2000).

In Anopheles dirus larvae, Enterobacter amnigenus bacteria isolated from their gut tissue were transformed with the mosquito-larvicidal toxin of Bacillus sphaericus 2297 (Khampang et al. 2001). The fragment encoding the binary toxin was inserted into various plasmids, under different promoters in order to improve expression levels. E. amnigenus carrying a recombinant plasmid with the native B. sphaericus promoter exhibited the highest toxicity among the plasmids that were tested and proved to be 20 times more effective than B. sphaericus 2297 (Khampang et al. 2001).

\section{INSECTICIDAL ACTIVITY OF ENTEROBACTER}

Apart from their beneficial impact on host fitness as members of the insect gut microbiota, Enterobacter strains may also exhibit insecticidal activity even against their hosts, functioning as biocontrol agents in pest management applications (Table 5). 
The shift in the behaviour of otherwise beneficial symbionts could be due to changes in the composition or location of the insect gut microbiota. Several examples of entomopathogenic Enterobacter strains have been documented. Among them, E. cloacae strain SL11 caused 30-73\% mortality, depending on bacteria concentration, when fed to larvae of its host Spodoptera litura (Thakur et al. 2015). The strain also had a negative impact on essential fitness parameters of $S$. litura progeny, including development from larva to adult, growth rate, life span, morphology and reproduction. The pathogenic E. cloacae strain dominated the gut microbiota in infected insects, caused a reduction in the number of haemocytes and produced immune responses of phenoloxidase and lysozyme (Thakur et al. 2015).

Table 5. Enterobacter species providing insecticidal activity

\begin{tabular}{|c|c|c|c|c|c|}
\hline $\begin{array}{l}\text { Enterobacter } \\
\text { Species }\end{array}$ & $\begin{array}{c}\text { Strain } \\
\text { Accession } \\
\text { Number }\end{array}$ & \multicolumn{2}{|l|}{ Host } & Function & Reference \\
\hline $\begin{array}{c}\text { Enterobacter } \\
\text { cloacae }\end{array}$ & КР058541 & $\begin{array}{c}\text { Spodoptera } \\
\text { litura } \\
\text { (Fabricius) }\end{array}$ & $\begin{array}{l}\text { Tobacco } \\
\text { cutworm }\end{array}$ & Insecticidal effect & $\begin{array}{c}\text { Thakur et al. } \\
2015\end{array}$ \\
\hline $\begin{array}{l}\text { Enterobacter } \\
\text { hormaechei, } \\
\text { Enterobacter } \\
\quad \text { sp. }\end{array}$ & $\begin{array}{l}\text { GU906249 } \\
\text { GU906251 }\end{array}$ & $\begin{array}{l}\text { Rhynchites } \\
\text { bacchus } \\
\text { (Linnaeus) }\end{array}$ & $\begin{array}{l}\text { Leafroller } \\
\text { weevil } \\
\text { beetles }\end{array}$ & Insecticidal effect & $\begin{array}{l}\text { Gokce et al. } \\
2010\end{array}$ \\
\hline $\begin{array}{c}\text { Enterobacter } \\
\text { cloacae }\end{array}$ & Not available & $\begin{array}{c}\text { Bemisia } \\
\text { argentifolii } \\
\text { Bellows \& } \\
\text { Perring }\end{array}$ & $\begin{array}{l}\text { Silverleaf } \\
\text { whitefly }\end{array}$ & Insecticidal effect & $\begin{array}{l}\text { Davidson et } \\
\text { al. } 2000\end{array}$ \\
\hline $\begin{array}{l}\text { Enterobacter } \\
\text { cancerogenus }\end{array}$ & Not available & $\begin{array}{l}\text { Oberea linearis } \\
\text { (Linnaeus) }\end{array}$ & $\begin{array}{l}\text { Hazelnut } \\
\text { and walnut } \\
\text { twig borer }\end{array}$ & Insecticidal effect & $\begin{array}{l}\text { Bahar and } \\
\text { Demirbağ } \\
2007\end{array}$ \\
\hline $\begin{array}{l}\text { Enterobacter } \\
\text { sp. }\end{array}$ & KM979225 & $\begin{array}{c}\text { Cimbex } \\
\text { quadrimaculatus } \\
\text { (Müller) }\end{array}$ & Sawfly & Insecticidal effect & $\begin{array}{l}\text { Cakici et al. } \\
2015\end{array}$ \\
\hline $\begin{array}{l}\text { Enterobacter } \\
\text { sp. }\end{array}$ & JQ066777 & $\begin{array}{l}\text { Spodoptera } \\
\text { littoralis } \\
\text { (Boisduval) }\end{array}$ & $\begin{array}{l}\text { Cotton } \\
\text { leafworm }\end{array}$ & Insecticidal effect & $\begin{array}{l}\text { Cakici et al. } \\
2015\end{array}$ \\
\hline $\begin{array}{c}\text { Enterobacter } \\
\text { aerogenes }\end{array}$ & Not available & $\begin{array}{c}\text { Euproctis } \\
\text { chrysorrhoea } \\
\text { (Linnaeus) }\end{array}$ & $\begin{array}{l}\text { Brown-tail } \\
\text { moth }\end{array}$ & Insecticidal effect & $\begin{array}{l}\text { Yaman et al. } \\
2000\end{array}$ \\
\hline $\begin{array}{l}\text { Enterobacter } \\
\text { aerogenes }\end{array}$ & AF306521 & $\begin{array}{c}\text { Myrmeleon bore } \\
\text { (Tjeder) }\end{array}$ & Antlion & Insecticidal effect & $\begin{array}{c}\text { Yoshida et al. } \\
2001\end{array}$ \\
\hline
\end{tabular}

Enterobacter strains with pathogenic effect against their host cause mortality in variable degree. In leafroller weevil beetles Rhynchites bacchus two Enterobacter strains (E. hormaechei Rb3 and Enterobacter sp. Rb5) caused 13\% mortality (Gokce et al. 2010) in the silverleaf whitefly, Bemisia argentifolii, E. cloacae WFA73 produced $34 \%$ adult $B$. argentifolii mortality after $24 \mathrm{~h}$ and $75 \%$ after $48 \mathrm{~h}$ (Davidson et al. 2000). E. cancerogenus Ol11 caused 15\% mortality in larvae of the beetle Oberea linearis ten days after treatment (Bahar and Demirbağ 2007). 
The larvicidal effect of Enterobacter sp. CQ4 resulted in 58\% mortality within ten days of third instar larvae of Cimbex quadrimaculatus (Çakici et al. 2015). In the cotton leafworm Spodoptera littoralis, Enterobacter sp. SL4 showed low larvicidal activity (17\%) against third instar larvae, ten days after treatment (Çakici et al. 2014). Finally, an Enterobacter aerogenes isolate from the brown-tail moth Euproctis chrysorrhoea caused 45\% mortality in third/fourth instar larvae (Yaman et al. 2000).

Yoshida et al. (2001) identified a mechanism of insecticidal activity based on a paralysing toxin that was produced by Enterobacter aerogenes bacteria contained in the saliva of Myrmeleon bore larvae. The $63 \mathrm{kDa}$ protein assists larvae in capturing their prey and shows homology to the heat shock protein GroEL of Escherichia coli. The two proteins share similar sequences that contain only a few differences, in 11 residues and the carboxy terminus. A series of individual mutations revealed crucial residues for toxicity. Specific substitutions resulted in the loss of insecticidal activity of the E. aerogenes protein or the development of toxic effect by the otherwise harmless GroEL chaperone (Yoshida et al. 2001).

\section{ENTEROBACTER GENOMICS}

The number of available genome sequences from the Enterobacter taxon has not reached a threshold where comparative genomics can drive hypotheses and experiments. Recent progress in the genomics era resulted in one complete genome sequence of Enterobacter cancerogenus CR-Eb1 isolated from the larval gut of the greater wax moth Galleria mellonella (Chung et al. 2018). Also, there are several draft genome sequences of Enterobacter strains available from other insects (Table 3). In order to fully utilize the powerful analysis of comparative genomics and draft genomes from Enterobacter strains, more genomic and transcriptomic data are required from Enterobacter strains covering diverse functional roles. The availability of these genomes will be able to assist us in understanding their functional roles by defining their differences and similarities in gene content (Khamis et al. 2019).

The availability of Enterobacter sequenced bacterial genomes will also allow a more profound understanding of their organizational features that are related to fundamental cellular processes such as coordinated gene expression, chromosome replication and cell division. Genomic data will provide the means to characterize the fluidity of bacterial chromosomes, including genome rearrangements that imperil the selective features of chromosome order. Furthermore, a high-density microarray can be developed for the analysis of expression and genome content in a wide variety of Enterobacter strains, both sequenced and not sequenced.

Comparative genomics of more complete Enterobacter genomes will also allow studying the integration process from free-living to endosymbiont. Usually, symbiotic bacteria undergo drastic genetic, phenotypic, and biochemical changes, which can be detected by comparison with free-living relatives (Lo et al. 2016). Genome reduction, in some cases, is extremely strong, and it has generated the smallest bacterial genomes found to date; gene contents are so limited that their status as cellular entities is questionable (Latorre and Manzano-Marín 2017). It would be exciting to further improve our understanding of Enterobacter species' diversity in terms of their evolutionary history. 


\section{CONCLUSIONS}

More than a hundred years of biological research has demonstrated the importance of microorganisms in the health and disease of higher organisms. Similarly, insects have symbiotic interactions that enable them to exploit unusually limited nutritional resources. In particular, recent findings suggest that symbiotic associations between insects and Enterobacter species may be beneficial to host fitness because of their various abilities to hydrolyse and ferment carbohydrates, catalyse nitrogen fixation, and produce vitamins and pheromones.

Also, the dominance of Enterobacter indicates an essential role in the protection of the insect host, or its nutritional resources, against parasitoids or predators, and also in terms of the interference in the transmission of malaria and other vector-borne diseases.

This review summarized our current knowledge of the relationship between Enterobacter and insect hosts. Characterization, exploitation and management of the insect-Enterobacter symbiotic associations can significantly contribute to and support integrated pest management applications for the control of agricultural pests and disease vectors.

To further decipher the Enterobacter-based symbiotic interactions we propose a systems biology approach in which, in silico predictions based on genomic analyses and phylogenetic information will be assessed by transcriptomic, proteomic, and metabolomic analyses. This information is considered essential for the success of downstream field applications.

\section{REFERENCES}

Adams, L., and R. Boopathy. 2005. Isolation and characterization of enteric bacteria from the hindgut of Formosan termite. Bioresource Technology 96: 1592-1598.

Adams, A. S., M. S. Jordan, S. M. Adams, G. Suen, L. A. Goodwin, K. W. Davenport, C. R. Currie, and K. F. Raffa. 2011. Cellulose-degrading bacteria associated with the invasive woodwasp Sirex noctilio. The International Society for Microbial Ecology (ISME) Journal 5: 1323-1331.

Adhav, A., S. Harne, A. Bhide, A. Giri, P. Gayathri, and R. Joshi. 2019. Mechanistic insights into enzymatic catalysis by trehalase from the insect gut endosymbiont Enterobacter cloacae. The Federation of European Biochemical Societies (FEBS) Journal 286: 1700-1716.

Akman, L., A. Yamashita, H. Watanabe, K. Oshima, T. Shiba, M. Hattori, and S. Aksoy. 2002. Genome sequence of the endocellular obligate symbiont of tsetse flies, Wigglesworthia glossinidia. Nature Genetics 32: 402-407.

Al-Ghamdi, A., K. Ali Khan, M. Javed Ansari, S. B. Almasaudi, and S. Al-Kahtani. 2018. Effect of gut bacterial isolates from Apis mellifera jemenitica on Paenibacillus larvae infected bee larvae. Saudi Journal of Biological Sciences 25: 383-387.

Aliota, M. T., S. A. Peinado, I. D. Velez, and J. E. Osorio. 2016a. The $w$ Mel strain of Wolbachia reduces transmission of Zika virus by Aedes aegypti. Scientific Reports 6: 28792.

Aliota, M. T., E. C. Walker, A. Uribe Yepes, I. Dario Velez, B. M. Christensen, and J. E. Osorio. 2016b. The $w \mathrm{Mel}$ strain of Wolbachia reduces transmission of Chikungunya virus in Aedes aegypti. PLoS Neglected Tropical Diseases 10.

Ant, T. H., C. S. Herd, V. Geoghegan, A. A. Hoffmann, and S. P. Sinkins. 2018. The Wolbachia strain $w$ Au provides highly efficient virus transmission blocking in Aedes aegypti. PLoS Pathogens 14: e1006815.

Armer, C. A., R. E. Berry, G. L. Reed, and S. J. Jepsen. 2004. Colorado potato beetle control by application of the entomopathogenic nematode Heterorhabditis marelata and potato plant alkaloid manipulation. Entomologia Experimentalis et Applicata 111: 47-58. 
Augustinos, A. A., G. A. Kyritsis, N. T. Papadopoulos, A. M. M. Abd-Alla, C. Cáceres, and K. Bourtzis. 2015. Exploitation of the medfly gut microbiota for the enhancement of Sterile Insect Technique: Use of Enterobacter sp. in larval diet-based probiotic applications. PLoS One 10: e0136459.

Augustinos, A. A., G. A. Kyritsis, C. Cáceres, and K. Bourtzis. 2021. Insect symbiosis in support of the Sterile Insect Technique, pp. 605-630. In V. A. Dyck, J. Hendrichs, and A. S. Robinson (eds.), Sterile Insect Technique - Principles and practice in Area-Wide Integrated Pest Management. Second Edition. CRC Press, Boca Raton, Florida, USA.

Bahar, A., and Z. Demirbağ. 2007. Isolation of pathogenic bacteria from Oberea linearis (Coleptera: Cerambycidae). Biologia 62: 13-18.

Bary, A. de. 1879. Die Erscheinung der Symbiose: Vortrag. Karl J. Trübner Verlag. Strassburg, Germany.

Behar, A., B. Yuval, and E. Jurkevitch. 2005. Enterobacteria-mediated nitrogen fixation in natural populations of the fruit fly Ceratitis capitata. Molecular Ecology 14: 2637-2643.

Ben Ami, E., B. Yuval, and E. Jurkevitch. 2009. Manipulation of the microbiota of mass-reared Mediterranean fruit flies Ceratitis capitata (Diptera: Tephritidae) improves sterile male sexual performance. The International Society for Microbial Ecology (ISME) Journal 4: 28.

Ben-Yosef, M., Z. Pasternak, E. Jurkevitch, and B. Yuval. 2014. Symbiotic bacteria enable olive flies (Bactrocera oleae) to exploit intractable sources of nitrogen. Journal of Evolutionary Biology 27: 2695-2705.

Bian, G., Y. Xu, P. Lu, Y. Xie, and Z. Xi. 2010. The endosymbiotic bacterium Wolbachia induces resistance to dengue virus in Aedes aegypti. PLoS Pathogens 6: 1-10.

Bian, G., D. Joshi, Y. Dong, P. Lu, G. Zhou, X. Pan, Y. Xu, G. Dimipoulos, and Z. Xi. 2013. Wolbachia invades Anopheles stephensi populations and induces refractoriness to Plasmodium infection. Science 340: 748-751.

Blackburn, M. B., D. E. Gundersen-Rindal, D. C. Weber, P. A. W. Martin, and R. R. Farrar. 2008. Enteric bacteria of field-collected Colorado potato beetle larvae inhibit growth of the entomopathogens Photorhabdus temperata and Beauveria bassiana. Biological Control 46: 434-441.

Bourtzis, K., and T. A. Miller (eds.). 2008. Insect symbiosis. CRC Press, Boca Raton, Florida, USA. 324 pp.

Brady, C., I. Cleenwerck, S. Venter, T. Coutinho, and P. De Vos. 2013. Taxonomic evaluation of the genus Enterobacter based on Multilocus Sequence Analysis (MLSA): Proposal to reclassify E. nimipressuralis and E. amnigenus into Lelliottia gen. nov. as Lelliottia nimipressuralis comb. nov. and Lelliottia amnigena comb. nov., respectively, E. gergoviae and E. pyrinus into Pluralibacter gen. nov. as Pluralibacter gergoviae comb. nov. and Pluralibacter pyrinus comb. nov., respectively, E. cowanii, E. radicincitans, E. oryzae and E. arachidis into Kosakonia gen. nov. as Kosakonia cowanii comb. nov., Kosakonia radicincitans comb. nov., Kosakonia oryzae comb. nov. and Kosakonia arachidis comb. nov., respectively, and E. turicensis, E. helveticus and E. pulveris into Cronobacter as Cronobacter zurichensis nom. nov., Cronobacter helveticus comb. nov. and Cronobacter pulveris comb. nov., respectively, and emended description of the genera Enterobacter and Cronobacter. Systematic and Applied Microbiology 36: 309-319.

Brenner, D. J., G. R. Fanning, and J. K. Leete Knutson. 1984. Attempts to classify herbicola groupEnterobacter agglomerans strains by deoxyribonucleic acid hybridization and phenotypic tests. International Journal of Systematic Bacteriology 34: 45-55.

Breznak, J. A., W. J. Brill, J. W. Mertins, and H. C. Coppel. 1973. Nitrogen fixation in termites. Nature 244: 577.

Bridges, J. R. 1981. Nitrogen-fixing bacteria associated with bark beetles. Microbial Ecology 7: 131-137.

Broderick, N. A., and B. Lemaitre. 2012. Gut-associated microbes of Drosophila melanogaster. Gut Microbes 3: 307-321.

Brown, C. T., L. A. Hug, B. C. Thomas, I. Sharon, C. J. Castelle, A. Singh, M. J. Wilkins, K. C. Wrighton, K. H. Williams, and J. B. Banfield. 2015. Unusual biology across a group comprising more than $15 \%$ of domain Bacteria. Nature 523: 208-211.

Brune, A., and C. Dietrich. 2015. The gut microbiota of termites: Digesting the diversity in the light of ecology and evolution. Annual Review of Microbiology 69: 145-166.

Butera, G., C. Ferraro, S. Colazza, G. Alonzo, and P. Quatrini. 2012. The culturable bacterial community of frass produced by larvae of Rhynchophorus ferrugineus Olivier (Coleoptera: Curculionidae) in the Canary island date palm. Letters in Applied Microbiology 54: 530-536. 
Cáceres, C., G. Tsiamis, B. Yuval, E. Jurkevitch, and K. Bourtzis. 2019. Joint FAO/IAEA coordinated research project on "Use of symbiotic bacteria to reduce mass-rearing costs and increase mating success in selected fruit pests in support of SIT application”. BMC Microbiology 19: 284.

Çakici, F. O., A. Sevõm, Z. Demõrbağ, and İ. Demõr. 2014. Investigating internal bacteria of Spodoptera littoralis (Boisd.) (Lepidoptera: Noctuidae) larvae and some Bacillus strains as biocontrol agents. Turkish Journal of Agriculture and Forestry 38: 99-110.

Çakici, F. O., I. Ozgen, H. Bolu, Z. Erbas, Z. Demirbă̆, and I. Demir. 2015. Highly effective bacterial agents against Cimbex quadrimaculatus (Hymenoptera: Cimbicidae): Isolation of bacteria and their insecticidal activities. World Journal of Microbiol Biotechnology 31: 59-67.

Cambon, M., J.-C. Ogier, A. Lanois, J.-B. Ferdy, and S. Gaudriault. 2018. Changes in rearing conditions rapidly modify gut microbiota structure in Tenebrio molitor larvae. bioRxiv: 423178 .

Capuzzo, C., G. Firrao, L. Mazzon, A. Squartini, and V. Girolami. 2005. 'Candidatus Erwinia dacicola', a coevolved symbiotic bacterium of the olive fly Bactrocera oleae (Gmelin). International Journal of Systematic and Evolutionary Microbiology 55: 1641-1647.

Chandler, J. A., J. M. Lang, S. Bhatnagar, J. A. Eisen, and A. Kopp. 2011. Bacterial communities of diverse Drosophila species: Ecological context of a host-microbe model system. PLoS Genetics 7: e1002272.

Chung, J., H. Jeong, and C.-M. Ryu. 2018. Complete genome sequences of Enterobacter cancerogenus CR-Eb1 and Enterococcus sp. strain CR-Ec1, isolated from the larval gut of the greater wax moth, Galleria mellonella. Genome Announcements 6: e00044-18.

Chung, S. H., C. Rosa, E. D. Scully, M. Peiffer, J. F. Tooker, K. Hoover, D. S. Luthe, and G. W. Felton. 2013. Herbivore exploits orally secreted bacteria to suppress plant defenses. Proceedings of the National Academy of Sciences of the USA 110: 15728-15733.

Cirimotich, C. M., A. M. Clayton, and G. Dimopoulos. 2011a. Low- and high-tech approaches to control Plasmodium parasite transmission by Anopheles mosquitoes. Journal of Tropical Medicine 2011: 891342.

Cirimotich, C. M., J. L. Ramirez, and G. Dimopoulos. 2011b. Native microbiota shape insect vector competence for human pathogens. Cell Host Microbe 10: 307-310.

Cirimotich, C. M., Y. Dong, A. M. Clayton, S. L. Sandiford, J. A. Souza-Neto, M. Mulenga, and D. Dimopoulos. 2011c. Natural microbe-mediated refractoriness to Plasmodium infection in Anopheles gambiae. Science 332: 855-858.

Colman, D. R., E. C. Toolson, and C. D. Takacs-Vesbach. 2012. Do diet and taxonomy influence insect gut bacterial communities? Molecular Ecology 21: 5124-5137.

Davidson, E. W., R. C. Rosell, and D. L. Hendrix. 2000. Culturable bacteria associated with the whitefly, Bemisia argentifolii (Homoptera: Aleyrodidae). The Florida Entomologist 83: 159-171.

Davin-Regli, A., and J.-M. Pagès. 2015. Enterobacter aerogenes and Enterobacter cloacae; versatile bacterial pathogens confronting antibiotic treatment. Frontiers in Microbiology 6: 392.

Dennison, N. J., N. Jupatanakul, and G. Dimopoulos. 2014. The mosquito microbiota influences vector competence for human pathogens. Current Opinion in Insect Science 3: 6-13.

Dong, Y, F. Manfredini, and G. Dimopoulos. 2009. Implication of the mosquito midgut microbiota in the defense against malaria parasites. PLoS Pathogens 5: e1000423.

Douglas, A. E. 2009. The microbial dimension in insect nutritional ecology. Functional Ecology 23: 3847.

Douglas, A. E. 2015. Multiorganismal insects: Diversity and function of resident microorganisms. Annual Review of Entomology 60: 17-34.

Doudoumis, V., A. M. M. Abd-Alla, G. Tsiamis, C. Brelsfoard, S. Aksoy, and K. Bourtzis. 2013. Tsetse-Wolbachia symbiosis: Comes of age and has great potential for pest and disease control. Journal of Invertebrate Pathology 112: S94-S103.

Doudoumis, V., F. Blow, A. Saridaki, A. Augustinos, N. A. Dyer, I. Goodhead, P. Solano, J.-B. Rayaisse, P. Takac, S. Mekonnen, A. G. Parker, A. M. M. Abd-Alla, A. Darby, K. Bourtzis, and G. Tsiamis. 2017. Challenging the Wigglesworthia, Sodalis, Wolbachia symbiosis dogma in tsetse flies: Spiroplasma is present in both laboratory and natural populations. Scientific Reports 7: 4699.

Drew, R. A. I., and A. C. Lloyd. 1987. Relationship of fruit flies (Diptera: Tephritidae) and their bacteria to host plants. Annals of the Entomological Society of America 80: 629-636.

Dutra, H. L. C, M. N. Rocha, F. B. S. Dias, S. B. Mansur, E. P. Caragata, and L. A. Moreira. 2016. Wolbachia blocks currently circulating zika virus isolates in Brazilian Aedes aegypti mosquitoes. Cell Host \& Microbe 19: 771-774. 
Eappen, A. G., R. C. Smith, and M. Jacobs-Lorena. 2013. Enterobacter-activated mosquito immune responses to Plasmodium involve activation of SRPN6 in Anopheles stephensi. PLoS One 8: e62937.

Engel, P., and N. A. Moran. 2013. The gut microbiota of insects - Diversity in structure and function. Federation of European Microbiological Societies (FEMS) Microbiology Reviews 37: 699-735.

Engel, P., W. K. Kwong, Q. McFrederick, K. E. Anderson, S. M. Barribeau, J. A. Chandler, R. Scott Cornman, J. Dainat, J. R. de Miranda, V. Doublet, O. Emery, J. D. Evans, L. Farinelli, M. L. Flenniken, F. Granberg, J. A. Grasis, L. Gauthier, J. Hayer, H. Koch, S. Kocher, V. G. Martinson, N. Moran, M. Munoz-Torres, I. Newton, R. J. Paxton, E. Powell, B. M. Sadd, P. Schnid-Hempel, S. J. Song, R. S. Schwarz, D. vanEngelsdorp, and B. Dainat. 2016. The bee microbiome: Impact on bee health and model for evolution and ecology of host-microbe interactions. mBio 7: e02164-15.

Eren, A. M., M. L. Sogin, H. G. Morrison, J. H. Vineis, J. C. Fisher, R. J. Newton, and S. L. McLellan. 2015. A single genus in the gut microbiome reflects host preference and specificity. The International Society for Microbial Ecology (ISME) Journal 9: 90-100.

Estes, A. M., D. J. Hearn, S. Agrawal, E. A. Pierson, and J. C. Dunning Hotopp. 2018a. Comparative genomics of the Erwinia and Enterobacter olive fly endosymbionts. Scientific Reports 8: 15936.

Estes, A. M., D. J. Hearn, S. Nadendla, E. A. Pierson, and J. C. Dunning Hotopp. 2018b. Draft genome sequence of Enterobacter sp. strain OLF, a colonizer of olive flies. Microbiology Resource Announcements 7: e01068-18.

Eutick, M. L., R. W. O'Brien, and M. Slaytor. 1978. Bacteria from the gut of Australian termites. Applied Environmental Microbiology 35: 823-828.

Fang, H., W. Chen, B. Wang, X. Li, S.-J. Liu, and H. Yang. 2016. Cultivation and characterization of symbiotic bacteria from the gut of Reticulitermes chinensis. Applied Environmental Biotechnology 1: $3-12$.

Feldhaar, H. 2011. Bacterial symbionts as mediators of ecologically important traits of insect hosts. Ecological Entomology 36: 533-543.

Fierer, N., and J. T. Lennon. 2011. The generation and maintenance of diversity in microbial communities. American Journal of Botany 98: 439-448.

Frentiu, F. D., T. Zakir, T. Walker, J. Popovici, A. T. Pyke, A. van den Hurk, E. A. McGraw, and S. L. O'Neill. 2014. Limited dengue virus replication in field-collected Aedes aegypti mosquitoes infected with Wolbachia. PLoS Neglected Tropical Diseases 8: e2688.

Geiger, A., M.-L. Fardeau, P. Grebaut, G. Vatunga, T. Josénando, S. Herder, G. Cuny, P. Truc, and B. Ollivier. 2009. First isolation of Enterobacter, Enterococcus, and Acinetobacter spp. as inhabitants of the tsetse fly (Glossina palpalis palpalis) midgut. Infection, Genetics and Evolution 9: 1364-1370.

Gibbons, S. M., and J. A. Gilbert. 2015. Microbial diversity - exploration of natural ecosystems and microbiomes. Current Opinion in Genetics \& Development 35: 66-72.

Gil, R., and A. Latorre. 2019. Unity makes strength: A review on mutualistic symbiosis in representative insect clades. Life (Basel) 9: e21.

Gokce, C., A. Sevim, Z. Demirbağ, and I. Demir. 2010. Isolation, characterization and pathogenicity of bacteria from Rhynchites bacchus (Coleoptera: Rhynchitidae). Biocontrol Science and Technology 20: 973-982.

Gonzalez-Ceron, L., F. Santillan, M. H. Rodriguez, D. Mendez, and J. E. Hernandez-Avila. 2003. Bacteria in midguts of field-collected Anopheles albimanus block Plasmodium vivax sporogonic development. Journal of Medical Entomology 40: 371-374.

Gujjar, N. R., S. Govindan, A. Verghese, S. Subramaniam, and R. More. 2017. Diversity of the cultivable gut bacterial communities associated with the fruit flies Bactrocera dorsalis and Bactrocera cucurbitae (Diptera: Tephritidae). Phytoparasitica 45: 453-460.

Gurung, K., B. Wertheim, and J. F. Salles. 2019. The microbiome of pest insects: It is not just bacteria. Entomologia Experimentalis et Applicata 167: 156-170.

Hamden, H., M. N. Guerfali, S. Fadhl, M. Saidi, and C. Chevrier. 2013. Fitness improvement of massreared sterile males of Ceratitis capitata (Vienna 8 strain) (Diptera: Tephritidae) after gut enrichment with probiotics. Journal of Economic Entomology 106: 641-647.

Hoffmann, H., and A. Roggenkamp. 2003. Population genetics of the nomenspecies Enterobacter cloacae. Applied Environmental Microbiology 69: 5306-5318.

Hoffmann, H., S. Stindl, A. Stumpf, A. Mehlen, D. Monget, J. Heesemann, K. H. Schleifer, and A. Roggenkamp. 2005. Description of Enterobacter ludwigii sp. nov., a novel Enterobacter species of clinical relevance. Systematic and Applied Microbiology 28: 206-212. 
Hormaeche, E., and P. R. Edwards. 1960. A proposed genus Enterobacter. International Bulletin of Bacteriological Nomenclature and Taxonomy 10: 71-74.

Husník, F., T. Chrudimský, and V. Hypša. 2011. Multiple origins of endosymbiosis within the Enterobacteriaceae $(\gamma$-Proteobacteria): Convergence of complex phylogenetic approaches. BMC Biology 9: 87.

Husseneder, C., and J. K. Grace. 2005. Genetically engineered termite gut bacteria (Enterobacter cloacae) deliver and spread foreign genes in termite colonies. Applied Microbiology and Biotechnology 68: 360-367.

Janusz, G., A. Pawlik, J. Sulej, U. Świderska-Burek, A. Jarosz-Wilkołazka, and A. Paszczyński. 2017. Lignin degradation: Microorganisms, enzymes involved, genomes analysis and evolution. Federation of European Microbiological Societies (FEMS) Microbiology Reviews 41: 941-962.

Jayakrishnan, L., A. V. Sudhikumar, and E. M. Aneesh. 2018. Role of gut inhabitants on vectorial capacity of mosquitoes. Journal of Vector Borne Diseases 55: 69.

Jiang, J., C. Alvarez, P. Kukutla, W. Yu, and J. Xu. 2012. Draft genome sequences of Enterobacter sp. isolate $\mathrm{Ag} 1$ from the midgut of the malaria mosquito Anopheles gambiae. Journal of Bacteriology 194: 5481-5481.

Jurkevitch, E. 2011. Riding the Trojan horse: Combating pest insects with their own symbionts. Microbial Biotechnology 4: 620-627.

Kalappa, D. M., P. A. Subramani, S. K. Basavanna, S. K. Ghosh, V. Sundaramurthy, S. Uragayala, S. Tiwari, A. R. Anvikar, and N. Valecha. 2018. Influence of midgut microbiota in Anopheles stephensi on Plasmodium berghei infections. Malaria Journal 17: 385.

Khamis, F. M., P. O. Mireji, F. L. O. Ombura, A. R. Malacrida, E. O. Awuoche, M. Rono, S. A. Mohamed, C. M. Tanga, and S. Ekesi. 2019. Species-specific transcriptional profiles of the gut and gut microbiome of Ceratitis quilicii and Ceratitis rosa sensu stricto. Scientific Reports 9: 18355.

Khampang, P., P. Luxananil, S. Tanapongpipat, W. Chungjatupornchai, and S. Panyim. 2001. Recombinant Enterobacter amnigenus highly toxic to Anopheles dirus mosquito larvae. Current Microbiology 43: 448-451.

Kohl, K. D., J. Amaya, C. A. Passement, M. D. Dearing, and M. D. McCue. 2014. Unique and shared responses of the gut microbiota to prolonged fasting: A comparative study across five classes of vertebrate hosts. Federation of European Microbiological Societies (FEMS) Microbiology Ecology 90: 883-894.

König, H., J. Fröhlich, and H. Hertel. 2006. Diversity and lignocellulolytic activities of cultured microorganisms, pp. 271-301. In H. König, and A. Varma (eds.), Intestinal microorganisms of termites and other invertebrates. Springer, Berlin-Heidelberg, Germany.

Kuhnigk, T., E.-M. Borst, A. Ritter, P. Kämpfer, A. Graf, H. Hertel, and H. König. 1994. Degradation of lignin monomers by the hindgut flora of xylophagous termites. Systematic and Applied Microbiology 17: 76-85.

Kumar, S., G. K. Christophides, R. Cantera, B. Charles, Y. S. Han, S. Meister, G. Dimipoulos, F. C. Kafatos, and C. Barilla-Mury. 2003. The role of reactive oxygen species on Plasmodium melanotic encapsulation in Anopheles gambiae. Proceedings National Academy of Sciences of the USA 100: 14139-14144.

Kyritsis, G. A., A. A. Augustinos, C. Cáceres, and K. Bourtzis. 2017. Medfly gut microbiota and enhancement of the Sterile Insect Technique: Similarities and differences of Klebsiella oxytoca and Enterobacter sp. AA26 probiotics during the larval and adult stages of the VIENNA 8D53+genetic sexing strain. Frontiers in Microbiology 8: 2064.

Latorre, A., and A. Manzano-Marín. 2017. Dissecting genome reduction and trait loss in insect endosymbionts. Annals of the New York Academy of Sciences 1389: 52-75.

Lauzon, C. R., S. E. Potter, and R. J. Prokopy. 2003. Degradation and detoxification of the dihydrochalcone phloridzin by Enterobacter agglomerans, a bacterium associated with the apple pest, Rhagoletis pomonella (Walsh) (Diptera: Tephritidae). Environmental Entomology 32: 953-962.

Ley, R. E., C. A. Lozupone, M. Hamady, R. Knight, and J. I. Gordon. 2008. Worlds within worlds: Evolution of the vertebrate gut microbiota. Nature Reviews Microbiology 6: 776-788.

Lo, W.-S., Y.-Y. Huang, and C.-H. Kuo. 2016. Winding paths to simplicity: Genome evolution in facultative insect symbionts. Federation of European Microbiological Societies (FEMS) Microbiology Reviews 40: 855-874.

Luckhart, S., Y. Vodovotz, L. Cui, and R. Rosenberg. 1998. The mosquito Anopheles stephensi limits malaria parasite development with inducible synthesis of nitric oxide. Proceedings of the National Academy of Sciences of the USA 95: 5700-5705. 
Manfredi, A. P., N. I. Perotti, and M. A. Martínez. 2015. Cellulose degrading bacteria isolated from industrial samples and the gut of native insects from Northwest of Argentina. Journal of Basic Microbiology 55: 1384-1393.

Mannesmann, R., and B. Piechowski. 1989. Verteilung von Gärkammerbakterien einiger Termitenarten. Materials and Organisms 24: 161-177.

Manzano-Marín, A., J.-C. Simon, and A. Latorre. 2016. Reinventing the wheel and making it round again: Evolutionary convergence in Buchnera-Serratia symbiotic consortia between the distantly related Lachninae aphids Tuberolachnus salignus and Cinara cedri. Genome Biology and Evolution 8: $1440-1458$.

Martin, B., and E. Schwab. 2012. Current usage of symbiosis and associated terminology. International Journal of Biology 5: 32 .

Mateos, M., H. Martinez, S. B. Lanzavecchia, C. Conte, K. Guillen, B. M. Moran-Aceves, J. Toledo, P. Liedo, E. D. Asimakis, V. Doudoumis, G. A. Kyritsis, N. T. Papadopoulos, A. A. Avgoustinos, D. F. Segura, G. Tsiamis, and K. Bourtzis. 2018. Wolbachia pipientis associated to tephritid fruit fly pests: From basic research to applications. bioRxiv: 358333.

Mathews, S. L., M. J. Epps, R. K. Blackburn, M. B. Goshe, A. M. Grunden, and R. R. Dunn. 2019. Public questions spur the discovery of new bacterial species associated with lignin bioconversion of industrial waste. Royal Society Open Science 6: 180748.

McFall-Ngai, M. 2007. Adaptive immunity: Care for the community. Nature 445: 153.

Mereghetti, V., B. Chouaia, and M. Montagna. 2017. New insights into the microbiota of moth pests. International Journal of Molecular Sciences 8: 2450.

Molina-Cruz, A., R. J. DeJong, B. Charles, L. Gupta, S. Kumar, G. Jaramillo-Gutierrez, and C. Barillas-Mury. 2008. Reactive oxygen species modulate Anopheles gambiae immunity against bacteria and Plasmodium. The Journal of Biological Chemistry 283: 3217-3223.

Moreira, L. A., I. Iturbe-Ormaetxe, J. A. Jeffery, G. Lu, A. T. Pyke, L. M. Hedges, B. C. Rocha, S. Hall-Mendelin, A. Day, M. Riegler, L. E. Hugo, K. N. Johnson, B. H. Kay, E. A. McGraw, A. F. van den Hurk, P. A, Ryan, and S. L. O'Neill. 2009. A Wolbachia symbiont in Aedes aegypti limits infection with dengue, Chikungunya, and Plasmodium. Cell 139: 1268-1278.

Moya, A., J. Peretó, R. Gil, and A. Latorre. 2008. Learning how to live together: Genomic insights into prokaryote-animal symbioses. Nature Reviews Genetics 9: 218-229.

Mramba, F., A, B. Broce, and L. Zurek. 2007. Vector competence of stable flies, Stomoxys calcitrans L. (Diptera: Muscidae), for Enterobacter sakazakii. Journal of Vector Ecology 32: 134-139.

Muhammad, A., Y. Fang, Y. Hou, and Z. Shi. 2017. The gut entomotype of red palm weevil Rhynchophorus ferrugineus Olivier (Coleoptera: Dryophthoridae) and their effect on host nutrition metabolism. Frontiers in Microbiology 8: 2291.

Murphy, K. M., D. S. Teakle, and I. C. MacRae. 1994. Kinetics of colonization of adult Queensland fruit flies (Bactrocera tryoni) by dinitrogen-fixing alimentary tract bacteria. Applied Environmental Microbiology 60: 2508-2517.

Nakabachi, A., A. Yamashita, H. Toh, H. Ishikawa, H. E. Dunbar, N. A. Moran, and M. Hattori. 2006. The 160-kilobase genome of the bacterial endosymbiont Carsonella. Science 314: 267.

Niyazi, N., C. R. Lauzon, and T. E. Shelly. 2004. Effect of probiotic adult diets on fitness components of sterile male Mediterranean fruit flies (Diptera: Tephritidae) under laboratory and field cage conditions. Journal of Economic Entomology 97: 1570-1580.

Octavia, S., and R. Lan. 2014. The family Enterobacteriaceae, pp. 225-286. In E. Rosenberg, E. F. DeLong, S. Lory, E. Stackebrandt, and F. Thompson (eds.), The Prokaryotes: Gammaproteobacteria. Springer, Berlin-Heidelberg, Germany.

Pereira, F. C., and D. Berry. 2017. Microbial nutrient niches in the gut. Environmental Microbiology 19: 1366-1378.

Pernice, M., S. J. Simpson, and F. Ponton. 2014. Towards an integrated understanding of gut microbiota using insects as model systems. Journal of Insect Physiology 69: 12-18.

Peterson, T. M. L., A. J. Gow, and S. Luckhart. 2007. Nitric oxide metabolites induced in Anopheles stephensi control malaria parasite infection. Free Radical Biology and Medicine 42: 132-142.

Potrikus, C. J., and J. A. Breznak. 1977. Nitrogen-fixing Enterobacter agglomerans isolated from guts of wood-eating termites. Applied Environmental Microbiology 33: 392-399.

Potrikus, C. J., and J. A. Breznak. 1981. Gut bacteria recycle uric acid nitrogen in termites: A strategy for nutrient conservation. Proceedings of the National Academy of Sciences of the USA 78: 46014605 . 
Ramin, M., A. R. Alimon, N. Abdullah, J. M. Panandam, and K. Sijam. 2008. Isolation and identification of three species of bacteria from the termite Coptotermes curvignathus (Holmgren) present in the vicinity of Universiti Putra Malaysia. Research Journal of Microbiology 3: 288-292.

Rizzi, A., E. Crotti, L. Borruso, C. Jucker, D. Lupi, M. Colombo, and D. Daffonchio. 2013. Characterization of the bacterial community associated with larvae and adults of Anoplophora chinensis collected in Italy by culture and culture-independent methods. BioMed Research International 2013: 420287.

Rojas-Jiménez, K., and M. Hernández. 2015. Isolation of fungi and bacteria associated with the guts of tropical wood-feeding Coleoptera and determination of their lignocellulolytic activities. International Journal of Microbiology 2015: 285018.

Rooks, M. G., and W. S. Garrett. 2016. Gut microbiota, metabolites and host immunity. Nature Reviews Immunology 16: 341-352.

Ruby, E., B. Henderson, and M. McFall-Ngai. 2004. We get by with a little help from our (little) friends. Science 303: 1305-1307.

Saldaña, M. A., S. Hegde, and G. L. Hughes. 2017. Microbial control of arthropod-borne disease. Memórias do Instituto Oswaldo Cruz 112: 81-93.

Sandeva, R., G. Sandeva, B. Chakarova, and A. Dimitrova. 2018. Gut microbiota - Our new important organ. Albanian Journal of Agricultural Sciences (Proceedings of ICOALS 2018): 175-181.

Schäfer, A., R. Konrad, T. Kuhnigk, P. Kämpfer, H. Hertel, and H. König. 1996. Hemicellulosedegrading bacteria and yeasts from the termite gut. Journal of Applied Bacteriology 80: 471-478.

Schmidt, T. L., N. H. Barton, G. Rašić, A. P. Turley, B. L. Montgomery, I. Iturbe-Ormaetxe, P. E. Cook, P. A. Ryan, S. A. Ritchie, A. A. Hoffmann, S. L. O'Neill, and M. Turelli. 2017. Local introduction and heterogeneous spatial spread of dengue-suppressing Wolbachia through an urban population of Aedes aegypti. PLoS Biology 15: 2001894.

Sheng, P., Y. Li, S. D. G. Marshall, and H. Zhang. 2015. High genetic diversity of microbial cellulase and hemicellulase genes in the hindgut of Holotrichia parallela larvae. International Journal of Molecular Science 16: 16545-16559.

Somerville, J., L. Zhou, and B. Raymond. 2019. Aseptic rearing and infection with gut bacteria improve the fitness of transgenic diamondback moth, Plutella xylostella. Insects 10: 89.

Szabó, G., F. Schulz, E. R. Toenshoff, J.-M. Volland, O. M. Finkel, S. Belkin, and M. Horn. 2017. Convergent patterns in the evolution of mealybug symbioses involving different intrabacterial symbionts. The International Society for Microbial Ecology (ISME) Journal 11: 715-726.

Tan, C. H., P. J. Wong, M. I. Li, H. Yang, L. C. Ng, and S. L. O'Neill. 2017. $w$ Mel limits zika and chikungunya virus infection in a Singapore Wolbachia-introgressed Ae. aegypti strain, wMel-Sg. PLoS Neglected Tropical Diseases 11: e. 0005496.

Tchioffo, M. T., A. Boissière, T. S. Churcher, L. Abate, G. Gimonneau, S. E. Nsango, P. H. AwonoAmbéné, R. Christen, A. Berry, and I. Morlais. 2013. Modulation of malaria infection in Anopheles gambiae mosquitoes exposed to natural midgut bacteria. PLoS One 8: e81663.

Thakur, A., P. Dhammi, H. S. Saini, and S. Kaur. 2015. Pathogenicity of bacteria isolated from gut of Spodoptera litura (Lepidoptera: Noctuidae) and fitness costs of insect associated with consumption of bacteria. Journal of Invertebrate Pathology 127: 38-46.

Thong-On, A., K. Suzuki, S. Noda, J. Inoue, S. Kajiwara, and M. Ohkuma. 2012. Isolation and characterization of anaerobic bacteria for symbiotic recycling of uric acid nitrogen in the gut of various termites. Microbes and Environments 27: 186-192.

Toczyłowska-Mamińska, R., K. Szymona, H. Madej, W. W. Zhen, A. Bala, W. Brutkowski, K. Krajewski, P. S. H'ng, and M. L. Maminski. 2015. Cellulolytic and electrogenic activity of Enterobacter cloacae in mediatorless microbial fuel cell. Applied Energy 160: 88-93.

Valero-Jiménez, C. A., A. J. Debets, J. A. van Kan, S. E. Schoustra, W. Takken, B. J. Zwaan, and C. J. M. Koenraadt. 2014. Natural variation in virulence of the entomopathogenic fungus Beauveria bassiana against malaria mosquitoes. Malaria Journal 13: 479.

van den Hurk, A. F., S. Hall-Mendelin, A. T. Pyke, F. D. Frentiu, K. McElroy, A. Day, S. Higgs, and S. L. O'Neill. 2012. Impact of Wolbachia on infection with chikungunya and yellow fever viruses in the mosquito vector Aedes aegypti. PLoS Neglected Tropical Diseases 6: e1892.

Vasanthakumar, A., I. Delalibera, J. Handelsman, K. D. Klepzig, P. D. Schloss, and K. F. Raffa. 2006. Characterization of gut-associated bacteria in larvae and adults of the southern pine beetle, Dendroctonus frontalis Zimmermann. Environmental Entomology 35: 1710-1717. 
Walker, T., P. H. Johnson, L. A. Moreira, I. Iturbe-Ormaetxe, F. D. Frentiu, C. J. McMeniman, Y. S. Leong, Y. Dong, J. Axford, P. Kriesner, A. L. Lloyd, S. A. Ritchie, S. L. O'Neill, and A. A. Hoffmann. 2011. The wMel Wolbachia strain blocks dengue and invades caged Aedes aegypti populations. Nature 476: 450-455.

Wang, H., L. Jin, T. Peng, H. Zhang, Q. Chen, and Y. Hua. 2014. Identification of cultivable bacteria in the intestinal tract of Bactrocera dorsalis from three different populations and determination of their attractive potential. Pest Management Science 70: 80-87.

Wang, J., S. H. Chung, M. Peiffer, C. Rosa, K. Hoover, R. Zeng, and G. W. Felton. 2016. Herbivore oral secreted bacteria trigger distinct defense responses in preferred and non-preferred host plants. Journal of Chemical Ecology 42: 463-474.

Wang, J., M. Peiffer, K. Hoover, C. Rosa, R. Zeng, and G. W. Felton. 2017. Helicoverpa zea gutassociated bacteria indirectly induce defenses in tomato by triggering a salivary elicitor(s). New Phytologist 214: 1294-1306.

Watanabe, K., K. Abe, and M. Sato. 2000. Biological control of an insect pest by gut-colonizing Enterobacter cloacae transformed with ice nucleation gene. Journal of Applied Microbiology 88: 9097.

Webster, N. S. 2014. Cooperation, communication, and co-evolution: Grand challenges in microbial symbiosis research. Frontiers in Microbiology 5: 164.

Weiss, B., and S. Aksoy. 2011. Microbiome influences on insect host vector competence. Trends in Parasitology 27: 514-522.

Wernegreen, J. J. 2004. Endosymbiosis: Lessons in conflict resolution. PLoS Biology 2: e68.

Whitman, W. B., D, C. Coleman, and W. J. Wiebe. 1998. Prokaryotes: The unseen majority. Proceedings of the National Academy of Sciences of the USA 95: 6578-6583.

Wilke, A. B. B., and M. T. Marrelli. 2015. Paratransgenesis: A promising new strategy for mosquito vector control. Parasites \& Vectors 8: 342.

Williams, L. E., and J. J. Wernegreen. 2010. Unprecedented loss of ammonia assimilation capability in a urease-encoding bacterial mutualist. BMC Genomics 11: 687.

Williams, T. A., G. J. Szöllősi, A. Spang, P. G. Foster, S. E. Heaps, B. Boussau, T. J. G. Ettema, and T. M. Embley. 2017. Integrative modeling of gene and genome evolution roots the archaeal tree of life. Proceedings of the National Academy of Sciences of the USA 114: E4602-4611.

Woodbury, N., and G. Gries. 2013a. How firebrats (Thysanura: Lepismatidae) detect and nutritionally benefit from their microbial symbionts Enterobacter cloacae and Mycotypha microspora. Environmental Entomology 42: 860-867.

Woodbury, N., and G. Gries. 2013b. Firebrats, Thermobia domestica, aggregate in response to the microbes Enterobacter cloacae and Mycotypha microspora. Entomologia Experimentalis et Applicata 147: $154-159$.

Wu, D., S. C. Daugherty, S. E. Van Aken, G. H. Pai, K. L. Watkins, H. Khouri, L. J. Tallon, J. M. Zaborsky, H. E. Dunbar, P. L. Tran, N. A. Moran, and J. A. Eisen. 2006. Metabolic complementarity and genomics of the dual bacterial symbiosis of sharpshooters. PLoS Biology 4: e188.

Xia, X., G. M. Gurr, L. Vasseur, D. Zheng, H. Zhong, B. Qin, J. Lin, Y. Wang, F.-Q. Song, Y. Li, H. Lin, and M. You. 2017. Metagenomic sequencing of diamondback moth gut microbiome unveils key holobiont adaptations for herbivory. Frontiers in Microbiology 8: 663.

Yaman, M., Z. Demirbağ, and A. O. Beldüz. 2000. Isolation and insecticidal effects of some bacteria from Euproctis chrysorrhoea L. (Lepidoptera: Lymantriidae). Acta Microbiologica Polonica 49: $217-$ 224.

Yao, M., H. Zhang, P. Cai, X. Gu, D. Wang, and Q. Ji. 2017. Enhanced fitness of a Bactrocera cucurbitae genetic sexing strain based on the addition of gut-isolated probiotics (Enterobacter spec.) to the larval diet. Entomologia Experimentalis et Applicata 162: 197-203.

Yoshida, N., K. Oeda, E. Watanabe, T. Mikami, Y. Fukita, K. Nishimura, K. Komai, and K. Matsuda. 2001. Protein function: Chaperonin turned insect toxin. Nature 411(6833): 44.

Yun, J.-H., S. W. Roh, T. W. Whon, M. J. Jung, M.-S. Kim, D.-S. Park, C. Yoon, Y.-D. Nam, Y.-J. Kim, J.-H. Choi, J.-Y. Kim, N.-R. Shin, S.-H. Kim, W.-J. Lee, and J.-W. Bae. 2014. Insect gut bacterial diversity determined by environmental habitat, diet, developmental stage, and phylogeny of host. Applied Environmental Microbiology 80: 5254-5264.

Yuval, B., E. Ben-Ami, A. Behar, M. Ben-Yosef, and E. Jurkevitch. 2013. The Mediterranean fruit fly and its bacteria - potential for improving Sterile Insect Technique operations. Journal of Applied Entomology 137: 39-42. 
Zaremba-Niedzwiedzka, K., E. F. Caceres, J. H. Saw, D. Bäckström, L. Juzokaite, E. Vancaester, K. W. Seitz, K. Anantharaman, P. Stamawski, K. U. Kjeldsen, M. B. Sott, T. Nunoura, J. F. Banfield, A. Schramm, B. J. Baker, A. Spang, and T. J. Ettema. 2017. Asgard archaea illuminate the origin of eukaryotic cellular complexity. Nature 541: 353-358.

Zchori-Fein, E., and S. J. Perlman. 2004. Distribution of the bacterial symbiont Cardinium in arthropods. Molecular Ecology 13: 2009-2016.

Zhang, H., W. Mu, Z. Hou, X. Wu, W. Zhao, X. Zhang, H. Pan, and S. Zhang. 2012. Biodegradation of nicosulfuron by the bacterium Serratia marcescens N80. Journal of Environmental Science Health B. 47: 153-160.

Zhang, G., M. Hussain, S. L. O'Neill, and S. Asgari. 2013. Wolbachia uses a host microRNA to regulate transcripts of a methyltransferase, contributing to dengue virus inhibition in Aedes aegypti. Proceedings of the National Academy of Sciences of the USA 110: 10276-10281.

Zhao, C., N. Tang, Y. Wu, Y. Zhang, Z. Wu, W. Li, X. Qin, J. Zhao, and G. Zhang. 2012. First reported fatal Morganella morganii infections in chickens. Veterinary Microbiology 156: 452-455.

Zhou, H., W. Guo, B. Xu, Z. Teng, D. Tao, Y. Lou, and Y. Gao. 2017. Screening and identification of lignin-degrading bacteria in termite gut and the construction of LiP-expressing recombinant Lactococcus lactis. Microbial Pathogenesis 112: 63-69.

Zhou, F., X. Wu, L. Xu, S. Guo, G. Chen, and X. Zhang. 2019. Repressed Beauveria bassiana infections in Delia antiqua due to associated microbiota. Pest Management Science 75: 170-179.

Zhu, B., M.-M. Lou, G.-L. Xie, G.-F. Wang, Q. Zhou, F. Wang, Y. Fang, T. Su, B. Lu, and Y.-P. Duan. 2011. Enterobacter mori sp. nov., associated with bacterial wilt on Morus alba L. International Journal of Systematic and Evolutionary Microbiology 61: 2769-2774. 